medRxiv preprint doi: https://doi.org/10.1101/2021.07.29.21260696; this version posted August 1, 2021. The copyright holder for this preprint (which was not certified by peer review) is the author/funder, who has granted medRxiv a license to display the preprint in All rights reserved. No reuse allowed without permission.

\title{
Failure of the choroid plexus in Alzheimer's disease
}

\author{
Maria Čarna ${ }^{1}$, Isaac G. Onyango ${ }^{1}$, Stanislav Katina ${ }^{1,2}$, Dušan Holub ${ }^{3}$, \\ Marketa Nezvedova ${ }^{4}$, Durga Jha ${ }^{4}$, Zuzana Nedelska ${ }^{1,5}$, Valentina Lacovich ${ }^{1}$, \\ Thijs Vande Vyvere ${ }^{6}$, Ruben Houbrechts ${ }^{6}$, Krystine Garcia-Mansfield ${ }^{7}$, Ritin Sharma ${ }^{7}$, \\ Victoria David-Dirgo ${ }^{7}$, Martin Vyhnalek ${ }^{1,5}$, Kateřina Texlova ${ }^{1}$, Hernan Chaves ${ }^{9}$, \\ Nadine Bakkar ${ }^{10}$, Lucia Pertierra ${ }^{9}$, Mojmir Vinkler ${ }^{2}$, Hana Markova ${ }^{1,5}$, Jan Laczo ${ }^{1,5}$, \\ Kateřina Sheardova ${ }^{1,11}$, Jan Frič ${ }^{1,12}$, Giancarlo Forte ${ }^{1}$, Petr Kaňovsky ${ }^{13}$, Silvie Belaškova ${ }^{1}$, \\ Jiri Damborsky ${ }^{1,4}$, Jakub Hort ${ }^{1,5}$, Nicholas T. Seyfried ${ }^{14,15,16}$, Robert Bowser ${ }^{10}$, \\ Gustavo Sevlever ${ }^{9}$, Robert A. Rissman ${ }^{17}$, Richard A. Smith ${ }^{18}$, Marian Hajduch ${ }^{3}$, \\ Patrick Pirrotte $^{7,8}$, Zdeněk Spačil ${ }^{4}$, Eric B. Dammer ${ }^{14,15,16}$, Clara Limbäck-Stokin ${ }^{19,}{ }^{20}$, \\ Gorazd B. Stokin ${ }^{1,21,22^{*}}$
}

${ }^{1}$ International Clinical Research Centre, St. Anne's University Hospital, Brno, Czech Republic

${ }^{2}$ Institute of Mathematics and Statistics, Masaryk University, Brno, Czech Republic ${ }^{3}$ Institute for Molecular and Translational Medicine, Faculty of Medicine and Dentistry, Palacky University Olomouc, Olomouc, Czech Republic

${ }^{4}$ RECETOX Centre, Faculty of Sciences, Masaryk University, Brno, Czech Republic

${ }^{5}$ Memory Clinic, Department of Neurology, $2^{\text {nd }}$ Faculty of Medicine, Charles University and Motol University Hospital, Prague, Czech Republic

${ }^{6}$ Icometrix, Leuven, Belgium

${ }^{7}$ Collaborative Center for Translational Mass Spectrometry, Translational Genomics Research Institute, Phoenix, USA

${ }^{8}$ Mass Spectrometry \& Proteomics Core Facility, City of Hope Comprehensive Cancer Center, Duarte, USA

${ }^{9}$ FLENI, Buenos Aires, Argentina

${ }^{10}$ Department of Neurobiology, Barrow Neurological Institute, Phoenix, Arizona, USA

${ }^{11} 1^{\text {st }}$ Department of Neurology, St. Anne's University Hospital and Faculty of Medicine, Masaryk University, Brno, Czech Republic

${ }^{12}$ Institute of Hematology and Blood Transfusion, Prague, Czech Republic

${ }^{13}$ Department of Neurology, Faculty of Medicine and Dentistry, Palacky University Olomouc and Research and Science Department, University Hospital Olomouc, Olomouc, Czech NOTE: This preprint reports new research that has not been certified by peer review and should not be used to guide clinical practice. Republic 
medRxiv preprint doi: https://doi.org/10.1101/2021.07.29.21260696; this version posted August 1, 2021. The copyright holder for this preprint (which was not certified by peer review) is the author/funder, who has granted medRxiv a license to display the preprint in All rights reserved. No reuse allowed without permission.

${ }^{14}$ Center for Neurodegenerative Disease, Emory University School of Medicine, Atlanta, USA

${ }^{15}$ Goizueta Alzheimer's Disease Research Center, Emory University, Atlanta, USA ${ }^{16}$ Departments of Biochemistry and Neurology, Emory University School of Medicine, Atlanta, USA

${ }^{17}$ Department of Neurosciences, University of California San Diego, La Jolla, USA

${ }^{18}$ Center for Neurologic Study, La Jolla, USA

${ }^{19}$ Department of Cellular Pathology, Imperial College Healthcare NHS Trust, London, UK

${ }^{20}$ Imperial College London, Faculty of Medicine, London, UK

${ }^{21}$ Division of Neurology, University Medical Centre, Ljubljana, Slovenia

${ }^{22}$ Translational Aging and Neuroscience Program, Mayo Clinic, Rochester, USA

*Corresponding author: gbstokin@,alumni.ucsd.edu 
medRxiv preprint doi: https://doi.org/10.1101/2021.07.29.21260696; this version posted August 1, 2021. The copyright holder for this preprint (which was not certified by peer review) is the author/funder, who has granted medRxiv a license to display the preprint in All rights reserved. No reuse allowed without permission.

\begin{abstract}
Alzheimer's disease is a neurodegenerative disorder characterized clinically by cognitive decline and pathologically by amyloid deposition and neurofibrillary changes. These neuropathological hallmarks are accompanied by reactive events including microglial activation and astrogliosis. The inflammatory response in Alzheimer's disease brains is distinguished by a pro-inflammatory signature involving amyloid peptides ${ }^{1}$, inflammasome signaling $^{2}$ and disrupted blood brain barrier ${ }^{3}$. Inflammatory changes are observed also in the cerebrospinal fluid in Alzheimer's disease ${ }^{4,5}$. It remains unknown, however, whether the choroid plexus which produces cerebrospinal fluid and guards the brain from peripheral inflammatory insults ${ }^{6,7}$, contributes to the inflammation and pathogenesis of Alzheimer's disease. Here we show that the choroid plexus in Alzheimer's disease exhibits a proinflammatory signature with aberrant protein accumulations, which contribute to the agedependent inflammatory changes observed in the cerebrospinal fluid. Magnetic resonance imaging reveals that the choroid plexus in patients with Alzheimer's disease displays pathological signal and increased volume, which inversely correlates with cognitive decline. Our findings suggest that the choroid plexus, being unable to efficiently resolve inflammatory insults over the lifetime, eventually ignites and drives the aberrant inflammatory response observed in Alzheimer's disease. These findings advance our understanding of the pathogenesis and open new vistas in the diagnostics and therapeutics of Alzheimer's disease.
\end{abstract}


medRxiv preprint doi: https://doi.org/10.1101/2021.07.29.21260696; this version posted August 1, 2021. The copyright holder for this preprint (which was not certified by peer review) is the author/funder, who has granted medRxiv a license to display the preprint in All rights reserved. No reuse allowed without permission.

The choroid plexus (ChP) is a grape-like structure protruding from each of the chambers that together constitute the ventricular system of the brain. It produces cerebrospinal fluid (CSF), which circulates between the ventricular system and the surface of the brain and the spinal cord to provide nutrients and remove waste. The ChP is composed of a fibroconnective stroma lined by a tight junction-bound epithelium; the stroma contains a rich network of fenestrated capillaries of peripheral vascular origin. This specific architecture creates the blood-CSF barrier (BCSFB), which secures optimal CSF composition and coordinates the crosstalk of the inflammatory signals between the brain and the periphery ${ }^{8-11}$.

Despite upregulating its host-defence programs ${ }^{12}$, the ChP becomes compromised during aging at the time when the brain acquires a pro-inflammatory signature ${ }^{13,14}$. Consistent with these findings, animal models of major age-related disorders such as Alzheimer's disease (AD), also exhibit inflammatory changes in the $\mathrm{ChP}^{15}$. In these models, the ChP shows increased levels of cytokines such as tumour necrosis factor alpha $(\mathrm{TNF} \alpha)^{16-18}$, perturbed secretion of proteins such as transthyretin (TTR) ${ }^{19}$, disruption of the $\mathrm{BCSFB}^{18,19}$ and reversal of select $\mathrm{AD}$ phenotypes by attenuating the ChP inflammatory response ${ }^{16,20}$. These findings, together with reported interaction between amyloid peptides and the ChP volume ${ }^{21}$, morphological changes of the $\mathrm{BCSFB}^{22,23}$ and impaired production and inflammatory abnormalities of the $\mathrm{CSF}^{4,5,24}$ in $\mathrm{AD}$ patients, all suggest a relationship between aging, $\mathrm{ChP}$ dysfunction and AD. Intriguingly, aberrancies in the apolipoprotein E (APOE), which is intimately linked to the pathogenesis of $\mathrm{AD}^{25}$ and plays an anti-inflammatory role in the $\mathrm{ChP}^{26}$, were recently also described in the $\mathrm{ChP}$ of patients with $\mathrm{AD}^{27}$. Possible roles of the $\mathrm{ChP}$ in the inflammation and pathogenesis of $\mathrm{AD}$, however, remain to be established. 
medRxiv preprint doi: https://doi.org/10.1101/2021.07.29.21260696; this version posted August 1, 2021. The copyright holder for this preprint (which was not certified by peer review) is the author/funder, who has granted medRxiv a license to display the preprint in All rights reserved. No reuse allowed without permission.

\section{Inflammatory changes in the $\mathrm{ChP}$ in $\mathrm{AD}$}

To test whether the ChP exhibits inflammatory changes in $\mathrm{AD}$, we first measured cytokines in lysates prepared from frozen post-mortem human ChP by a well-established ELISArray (Supplementary Tbl. 1). We found that ChP demonstrates increased levels of Interleukin (IL) 2 (IL-2), IL-4, TNF $\alpha$ and tumour growth factor $\beta$ (TGF $\beta$ ) levels, but not of IL-6, IL-10 and other cytokines, in AD compared with cognitively healthy individuals (H, Fig. 1a). To confirm this finding, we separated ChP lysates by SDS-PAGE and probed the blots for select cytokines. Blots showed increased levels of IL-2, TNF $\alpha$ and TGF $\beta$, but not of IL-6 and IL-10, in the ChP lysates in AD compared with H (Fig. 1b). Since these experiments showed humoral inflammatory response of the $\mathrm{ChP}$ in $\mathrm{AD}$, we examined $\mathrm{ChP}$ for inflammatory infiltrates and other pathologies. Haematoxylin and eosin-stained formalin fixed tissue sections of $\mathrm{ChP}$ harvested from the lateral ventricles showed no inflammatory infiltrates or other overt pathologies apart from age-related changes common to both, $\mathrm{H}$ and $\mathrm{AD}^{28}$ (Supplementary Tbl. 2, Extended Data Fig. 1a-c). We next probed ChP with anti-CD68 and anti-CD3 antibodies which label macrophages and $\mathrm{T}$ lymphocytes respectively, to test further for inflammatory infiltrates in the $\mathrm{ChP}$ in $\mathrm{AD}$. We found no difference in the number of $\mathrm{ChP}$ resident anti-CD68 positive cells between $\mathrm{H}$ and $\mathrm{AD}$, while the anti-CD3 positive cells were rarely ever observed (Extended Data Fig. 1d-f). To control for region specific pathologies, we analysed $\mathrm{ChP}$ harvested from the temporal horns of the lateral ventricles (Supplementary Tbl. 3). No inflammatory infiltrates, AD hallmark lesions or other overt ChP pathologies were found in $\mathrm{AD}$ compared with $\mathrm{H}$ (Extended Data Fig. 2). These results show that $\mathrm{ChP}$ in $\mathrm{AD}$ exhibits impaired humoral inflammatory response characterized by an imbalance between the pro- and anti-inflammatory cytokines.

\section{Inflammatory changes in the CSF in AD}

We next investigated whether inflammatory changes in the CSF accompany the proinflammatory state of the $\mathrm{ChP}$ observed in $\mathrm{AD}$. Considering that aging is the most important risk factor for $\mathrm{AD}$ and plays an equally important role in inflammation ${ }^{29}$, we first mined a well-established CSF dataset ${ }^{30,31}$ for age-related changes. Mining showed abundant representation of inflammatory events among the top 20 most significantly changed pathways in the CSF by aging (Fig 2a). When we compared the most significantly changed pathways in the CSF by aging between $\mathrm{H}$ and $\mathrm{AD}$, we identified several inflammatory and in particular complement-related pathways enriched in AD (Fig 2b). Since this established a link between inflammation, aging and $\mathrm{AD}$, we next investigated CSF inflammatory changes in different age 
medRxiv preprint doi: https://doi.org/10.1101/2021.07.29.21260696; this version posted August 1, 2021. The copyright holder for this preprint (which was not certified by peer review) is the author/funder, who has granted medRxiv a license to display the preprint in All rights reserved. No reuse allowed without permission.

groups (Supplementary Tbl. 4). We found that the 55-65 and 66-75 year-old age groups, which either precede or coincide with the most common age of onset of $\mathrm{AD}^{32}$, respectively, demonstrate the most pronounced CSF changes between $\mathrm{H}$ and AD (Fig. 2c, Extended Data Tbl. 1). We also observed a preponderant increase of CSF proteins in AD compared with $\mathrm{H}$ as previously reported ${ }^{30}$ (Fig. 2d). Metabolic and inflammatory pathways demonstrated the most common significant changes in the CSF in $\mathrm{AD}$ versus $\mathrm{H}$ across all age groups (Fig. 2e). Inflammatory changes showed significant differences between the age-groups (Fig. 2f).

These findings provide compelling evidence that aging plays an important role in the inflammatory response of the $\mathrm{CSF}$ in $\mathrm{AD}$, but are not informative regarding the extent to which these changes are unique to $\mathrm{AD}$. Consequently, we compared proteins identified by two independent mass spectrometry protocols in the CSF harvested from individuals afflicted by mild cognitive impairment (MCI) or dementia due to $\mathrm{AD}$ with a different neurodegenerative disorder, the amyotrophic lateral sclerosis (ALS) and a canonical inflammatory disease, Lyme disease (Lyme) (Fig. 2g, Extended Data Fig. 3, Extended Data Tbl. 2, Supplementary Tbl. 5). We identified several CSF proteins that are either unique or shared between the disorders compared with AD (Fig. 2h, Extended Data Tbl. 3). In contrast to MCI, which showed no significant changes compared to $\mathrm{AD}$, ingenuity pathway analysis showed significant differences between ALS and Lyme compared with AD CSF including their inflammatory profiles (Fig. 2i, j, Extended Data Fig. 4, 5). Thus, consistent with the inflammatory changes of the $\mathrm{ChP}$ in $\mathrm{AD}, \mathrm{CSF}$ also exhibits an inflammatory response in $\mathrm{AD}$, which differs from ones observed in a different neurodegenerative and canonical inflammatory disorders. Moreover, this response is qualitatively similar to MCI, which in our study represents early stage $\mathrm{AD}$.

\section{Impaired function of the ChP in AD}

Several CSF proteins are produced and reside in the $\mathrm{ChP}^{33}$. This suggests that CSF protein changes in $\mathrm{AD}$ may actually reflect their perturbations in the ChP. To test this hypothesis, we randomly selected a subset of proteins identified in our CSF cohorts for $\mathrm{H}$ and AD, validated their proteotypic peptide sequences by matching them to the isotopically labelled standards (Extended Data Fig. 6) and then measured their concentrations in the ChP by mass spectrometry. While comparing AD to $\mathrm{H}$, we found increased levels of NPC2 in both the CSF and the ChP, increased levels of TPI1, CD44 and LDHB in the CSF, but not in the ChP and no changes in IGHG2, APOE and ADAM22 in the CSF nor in the ChP (Fig. 3a, b). These findings indicated the involvement of the $\mathrm{ChP}$ as well as of other structures ${ }^{34}$ in the CSF 
medRxiv preprint doi: https://doi.org/10.1101/2021.07.29.21260696; this version posted August 1, 2021. The copyright holder for this preprint (which was not certified by peer review) is the author/funder, who has granted medRxiv a license to display the preprint in All rights reserved. No reuse allowed without permission.

protein changes observed in $\mathrm{AD}$. To investigate the involvement of the $\mathrm{ChP}$ in $\mathrm{AD}$ further, we stained ChP with anti-NPC2 and anti-APOE antibodies. Compared to H, we confirmed increased NPC2 immunoreactivity in AD, particularly in the epithelium of the ChP (Fig. 3ce). Intriguingly, although we stained for APOE as a negative control, enhanced APOE immunoreactivity and loss of the ring-like appearance suggested redistribution of APOE in the $\mathrm{ChP}$ in $\mathrm{AD}$ compared with $\mathrm{H}$. To further test for aberrant protein changes within the $\mathrm{ChP}$ in $\mathrm{AD}$, we last measured and stained for TTR, an abundant ChP resident protein, extensively reported to be changed in the CSF in AD (Supplementary Tbl. 6). Measurements showed increased levels and diffusely increased immunoreactivity of TTR in the ChP in AD compared with H (Fig. 3f, g).

Considering previous work showed that NPC2 deficiency increases cholesterol and lipid levels ${ }^{35}$, we asked whether the increased NPC2 levels observed in the ChP in AD are accompanied by concomitant reduction in cholesterol and lipid levels. We found reduced GM1 levels, but not of cholesterol, gangliosides or other lipids in the ChP in AD compared with H (Fig. 3h, Extended Data Fig. 7-9). Collectively, these findings indicate perturbed ChP function, which partly contributes to the CSF changes in AD. Moreover, increased NPC2 and reduced anti-inflammatory GM1 levels are suggestive of causality and further corroborate the pro-inflammatory state of the $\mathrm{ChP}$ in $\mathrm{AD}$.

\section{Enlarged ChP in AD exhibits pathological signal}

While our findings suggest functional failure of the $\mathrm{ChP}$ in $\mathrm{AD}$ on tissue samples, the clinical relevance of these findings is yet to be elucidated. To investigate their clinical relevance, we examined the ChP by magnetic resonance imaging (MRI). Analysis of MRI T1-weighted sequences showed increased normalized intensities of the ChP in AD compared with $\mathrm{H}$ (Fig. 4a, Supplementary Tbl. 7). We next segmented T1-weighted sequences and first measured hippocampal and cerebellar cortical volumes, regions we selected as positive and negative controls (Supplementary Tbl. 8). As previously reported ${ }^{36}$, we found decreased hippocampal and unchanged cerebellar cortical volumes in AD compared with $\mathrm{H}$. We next examined $\mathrm{ChP}$ and found increased $\mathrm{ChP}$ volumes in $\mathrm{AD}$ compared with $\mathrm{H}$ (Fig. 4b), which correlated inversely with the Mini-Mental State Examination (MMSE) scores in AD, but not in $\mathrm{H}$ (Fig. 4c). To characterize $\mathrm{ChP}$ in $\mathrm{AD}$ further, we created 3-dimensional (3D) representations (Supplementary Tbl. 9), which revealed significant remodelling of $\mathrm{ChP}$ in $\mathrm{AD}$ with atrophic changes along the anterior margin and hypertrophy in its posterior parts (Fig. 4d, e). To correct for segmentation and other errors, we also measured $\mathrm{ChP}$ volumes manually 
medRxiv preprint doi: https://doi.org/10.1101/2021.07.29.21260696; this version posted August 1, 2021. The copyright holder for this preprint (which was not certified by peer review) is the author/funder, who has granted medRxiv a license to display the preprint in perpetuity.

All rights reserved. No reuse allowed without permission.

(Supplementary Tbl. 10). Measurements showed no overlap between the 95\% confidence intervals of $\mathrm{ChP}$ volumes between $\mathrm{AD}$ and $\mathrm{H}$ (Fig. 4f). To reduce the confounding effect of sampling an individual cohort, we measured brain volumes also in a separate "confirmatory" cohort (Supplementary Tbl. 11). These measurements confirmed our previous observation of increased ChP volumes in AD compared with $\mathrm{H}$ (Extended Data Fig. 10). Taken together, our experiments demonstrate enlarged $\mathrm{ChP}$ exhibiting pathological signal in $\mathrm{AD}$, which correlates with cognitive decline. 
medRxiv preprint doi: https://doi.org/10.1101/2021.07.29.21260696; this version posted August 1, 2021. The copyright holder for this

preprint (which was not certified by peer review) is the author/funder, who has granted medRxiv a license to display the preprint in

All rights reserved. No reuse allowed without permission.

\section{Conclusions}

Aging promotes a pro-inflammatory state by disrupting the peripheral immune system leading to excessive innate immune activity with release of pro-inflammatory cytokines and decrease in anti-inflammatory molecules ${ }^{37}$. This pro-inflammatory state is well-described in the aging brain where it is sustained by the upregulation of pro-inflammatory genes ${ }^{38,39}$. In the chronic inflammation in the context of $\mathrm{AD}$, there is a close association between glial activation, inflammasome signaling and amyloid pathology $y^{1,2}$. This inflammatory landscape in AD is further compromised by adverse communication between the brain and the periphery due to disrupted blood brain barrier ${ }^{40,41}$.

Here we provide evidence of failed $\mathrm{ChP}$ function in $\mathrm{AD}$ which consists in inflammatory, protein and ganglioside perturbations and in part contributes to the specific CSF proteome changes observed in $\mathrm{AD}$. Our findings suggest that with age, the $\mathrm{ChP}$ in $\mathrm{AD}$ becomes unable to resolve injuries caused by peripheral inflammatory insults. This eventually translates into an impaired inflammatory response and dysfunction of the $\mathrm{ChP}$ that contributes to the chronic inflammation and the pathogenesis of AD. Importantly, identified failure of the $\mathrm{ChP}$ is clinically measurable and reflects cognitive decline in AD. The clinical relevance of our findings are insight into novel innovative diagnostic and therapeutic approaches for $\mathrm{AD}^{42}$, besides advancing the understanding of $\mathrm{AD}$ pathogenesis. 
medRxiv preprint doi: https://doi.org/10.1101/2021.07.29.21260696; this version posted August 1, 2021. The copyright holder for this preprint (which was not certified by peer review) is the author/funder, who has granted medRxiv a license to display the preprint in All rights reserved. No reuse allowed without permission.

\section{Figures}

Figure 1 - Imbalance between pro- and anti-inflammatory cytokines in the ChP in AD a, Levels of IL-2, IL-4, IL-5, IL-6, IL-10, IL-12, IL-13, IL-17a, interferon $\gamma($ IFN $\gamma)$, TNF $\alpha$, granulocyte colony stimulating factor (G-CSF) and TGF $\beta$ in the $\mathrm{ChP}$ in $\mathrm{H}$ and $\mathrm{AD}$ (both $\mathrm{n}=5$ ). Mean of 3 technical replicates per sample \pm s.e.m.; two-sample $t$-test $(\mathrm{p} \leq 0.05)$. b, Representative Western blots probed for IL-2, IL-6, IL-10, TNF $\alpha$ and TGF $\beta$ in the ChP in H and $\mathrm{AD}$ (both $\mathrm{n}=5$ ). All measurements were normalized for $\beta$-actin. Mean of 3 technical replicates per sample \pm s.e.m.; two-sample $t$-test $(\mathrm{p} \leq 0.05)$.

Figure 2 - Inflammatory changes in the CSF in AD a, The most significant ingenuity pathway based age-related CSF changes $(n=297, p \leq 0.05$, inflammatory changes in red). $\mathbf{b}$, The most significant ingenuity pathway based age-related CSF changes in $H(n=147, p \leq 0.05)$ and $\mathrm{AD}(\mathrm{n}=150)$. c, Venn diagram showing significantly changed CSF proteins in AD compared with $H$ in 45-55 $(n=29), 56-65(n=97), 66-75(n=133)$ and 76-90 $(n=38)$ year-old age groups $(\mathrm{p} \leq 0.05)$. d, Volcano plot showing significantly increased and decreased CSF protein levels in $\mathrm{AD}$ compared with $\mathrm{H}$ in different age groups ( $\mathrm{p} \leq 0.05, \mathrm{NS}$ : not significant). $\mathbf{e}$, Dot plot showing the most significant ingenuity pathway based age-related CSF changes in $\mathrm{AD}$ compared with $\mathrm{H}$ in different age groups $(\mathrm{p} \leq 0.05)$. f, Bar plot showing significantly changed inflammation-related biological processes in $\mathrm{AD}$ compared with $\mathrm{H}$ in different age groups. g, Heatmap representing hierarchically clustered CSF proteins identified by both independent mass spectrometry protocols (A and B) in MCI ( $\mathrm{n}=10), \operatorname{AD}(\mathrm{n}=22), \operatorname{ALS}(\mathrm{n}=14)$ and Lyme $(n=12)(p \leq 0.05$ FDR adjusted t-test). $\mathbf{h}$, Venn diagram showing CSF proteins identified by both independent mass spectrometry protocols (A and B) in MCI, ALS and Lyme significantly changed in comparison with $A D(p \leq 0.05)$. $\mathbf{i}$, Dot plot showing the most common significantly changed pathways in MCI, ALS and Lyme compared with AD $(\mathrm{p} \leq 0.05)$. j, Circular netplots showing CSF inflammatory protein and pathway significantly changed in AD compared with ALS and Lyme.

Figure 3 - Impaired ChP function in AD a, TPI1, CD44, LDHB, IGHG2, APOE, NPC2 and ADAM22 CSF protein levels in different $\mathrm{H}(\mathrm{n}=147)$ and $\mathrm{AD}(\mathrm{n}=150)$ age-groups analysed using the same data set as in the previous figure, a-f $(\mathrm{p} \leq 0.05)$. b, TPI1, CD44, LDHB, IGHG2, APOE, NPC2 and ADAM22 protein levels in the ChP of $\mathrm{H}(\mathrm{n}=5)$ and AD $(\mathrm{n}=5)$. Mean of 6 technical replicates per sample \pm s.e.m.; two-sample $t$-test $(\mathrm{p} \leq 0.05)$. $\mathbf{c}$, 
medRxiv preprint doi: https://doi.org/10.1101/2021.07.29.21260696; this version posted August 1, 2021. The copyright holder for this preprint (which was not certified by peer review) is the author/funder, who has granted medRxiv a license to display the preprint in All rights reserved. No reuse allowed without permission.

Representative image of scanned ChP tissue section (magnification bar $100 \mu$ ). d, Mean intensities of NPC2 and APOE in the ChP in H $(n=5)$ and AD $(n=5)$. Mean of 90 technical replicates per sample \pm s.e.m.; two-sample $t$-test $(\mathrm{p} \leq 0.05)$. e, Mean intensities of NPC2 and APOE in the ChP epithelium and stroma in $\mathrm{H}(\mathrm{n}=5)$ and $\mathrm{AD}(\mathrm{n}=5)$ (magnification bar $10 \mu)$. Mean of 3-12 technical replicates \pm s.e.m.; repeated measures $(\mathrm{p} \leq 0.05)$. f, Protein levels and mean intensity of TTR in the $\mathrm{ChP}$ in $\mathrm{H}(\mathrm{n}=5)$ and $\mathrm{AD}(\mathrm{n}=5)$. For protein levels: mean of 6 technical replicates per sample \pm s.e.m.; two-sample $t$-test $(\mathrm{p} \leq 0.05)$. For mean intensity: mean of 90 technical replicates per sample \pm s.e.m.; two-sample $t$-test $(\mathrm{p} \leq 0.05)$. g, Mean intensities of TTR in the ChP epithelium and stroma in $\mathrm{H}(\mathrm{n}=5)$ and $\mathrm{AD}(\mathrm{n}=5)$ (magnification bar $10 \mu)$. Mean of 3-12 technical replicates \pm s.e.m.; repeated measures $(\mathrm{p} \leq 0.05)$. h, Levels of GM1, GM2, GM3, GD1a, GD1b, GD2, GD3 and GT1b gangliosides in the ChP in $\mathrm{H}(\mathrm{n}=5)$ and AD $(\mathrm{n}=5) \mathrm{ChP}$. Mean of 6 technical replicates per sample \pm s.e.m.; two-sample $t$-test $(\mathrm{p} \leq 0.05)$.

Figure 4 - Abnormal MRI signal of enlarged ChP in AD patients a, Coronal, sagittal and axial views of $\mathrm{ChP}$ representative of $\mathrm{H}$ and $\mathrm{AD}$, respectively, visualized using $\mathrm{T} 1$-weighted sequence (top), FreeSurfer brain structure map (middle) and following ChP segmentation (bottom). Measurements of normalized $\mathrm{ChP}$ intensities in $\mathrm{H}(\mathrm{n}=9)$ and $\mathrm{AD}(\mathrm{n}=10)$. Individual measurements \pm s.e.m.; two-sample $t$-test $(\mathrm{p} \leq 0.05)$. b. Measurement of normalized $\mathrm{ChP}$ volumes of cerebellar cortex, hippocampus and $\mathrm{ChP}$ in $\mathrm{H}(\mathrm{n}=38)$ and $\mathrm{AD}(\mathrm{n}=80)$. 3D brain reconstruction depicts segmented $\mathrm{ChP}$ (red) within the ventricular system (blue) of the brain. Individual measurements \pm s.e.m.; two-sample $t$-test $(\mathrm{p} \leq 0.05)$. c, Correlation between normalized $\mathrm{ChP}$ volumes and MMSE scores in $\mathrm{H}(\mathrm{n}=15)$ and $\mathrm{AD}(\mathrm{n}=51)$. Individual measurements \pm s.e.m. d, T1-weighted sequence derived coronal, sagittal and axial views of the $\mathrm{ChP}$ (in red) and the coronal view of the post-mortem ChP (red asterisk) in the right lateral ventricle. e, 3D reconstructions and measurements of normalized hippocampal and $\mathrm{ChP}$ volumes in $\mathrm{H}(\mathrm{n}=23)$ and $\mathrm{AD}(\mathrm{n}=36)$. Single measurements \pm s.e.m.; two-sample $t$-test $(\mathrm{p} \leq 0.05)$. f, $95 \%$ confidence intervals of normalized, 3D reconstructed and manually measured ChP volumes. Representative 3D image shows manually traced $\mathrm{ChP}$ structure (red). 
medRxiv preprint doi: https://doi.org/10.1101/2021.07.29.21260696; this version posted August 1, 2021. The copyright holder for this preprint (which was not certified by peer review) is the author/funder, who has granted medRxiv a license to display the preprint in All rights reserved. No reuse allowed without permission.

\section{Methods}

\section{Study participants}

Majority of MRI images and CSF samples were acquired through the International Clinical Research Centre of St. Anne's University Hospital, which funds the Czech Brain Aging Study $^{43}$ running in the Departments of Neurology at Motol and St. Anne's University Hospitals, Prague and Brno, respectively. A total of 118 living individuals were examined in the original MRI study including 38 cognitively healthy individuals and 80 patients with AD (Supplementary Table 8). The average age of cognitively healthy individuals was $70.0 \pm 6.4$ years (mean \pm s.d.) and $75.0 \pm 7.6$ years for patients with AD. The average MMSE scores for

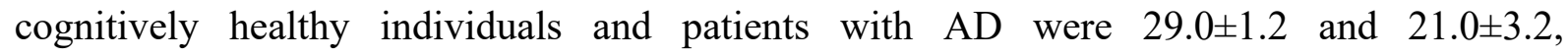
respectively. Randomly selected subsets of individuals of the original MRI study were also used for the assessment of the MRI intensities (Supplementary Table 7), 3D reconstructions (Supplementary Table 9) and for the manual measurements of the ChP (Supplementary Table $10)$.

Additional 23 living individuals from the Argentina Alzheimer's Disease Neuroimaging Initiative $^{44}$ were examined in the confirmatory MRI study including 13 cognitively healthy individuals and 10 patients with AD (Supplementary Table 11).

To maximize the use of publicly available data, we evaluated age-related CSF protein changes by mining a well-established CSF protein database (https://www.synapse.org/Consensus) $)^{30,31}$. The set consisted in data from a total of 297 individuals, including 147 healthy individuals and 150 patients with AD. The average age of cognitively healthy individuals was $65.1 \pm 8.2$ years and 68.2 \pm 8.3 years for patients with $\mathrm{AD}$ (Supplementary Table 4). The average Montreal Cognitive Assessment (MoCA) scores for cognitively healthy individuals and patients with $\mathrm{AD}$ were $25.5 \pm 3.1$ and $14.8 \pm 7.4$, respectively.

A total of 58 living individuals, part of the Czech Brain Aging Study ${ }^{43}$, were evaluated for changes in the CSF including 10 patients with MCI due to $\mathrm{AD}, 22$ patients with $\mathrm{AD}$ dementia, 14 patients with $\operatorname{ALS}^{45}$ (all from the Barrow Neurological Institute, Phoenix) and 12 patients with Lyme disease (Supplementary Table 5). The average age was 73.2 $\pm 7.0,71.6 \pm 9.0$, $55.8 \pm 8.7$ and $69.7 \pm 4.3$ years for patients with MCI, AD, ALS and Lyme disease, respectively. The average MMSE scores were 26.6 \pm 1.4 and $18.3 \pm 4.5$ for patients with MCI and $\mathrm{AD}$, respectively.

A total of 10 individuals provided post-mortem frozen $\mathrm{ChP}$ tissue through the Shiley-Marcos Alzheimer's Disease Research Centre (ADRC) of the University of California San Diego (UCSD). Tissue included ChP from 5 cognitively healthy individuals and 5 patients with 
medRxiv preprint doi: https://doi.org/10.1101/2021.07.29.21260696; this version posted August 1, 2021. The copyright holder for this preprint (which was not certified by peer review) is the author/funder, who has granted medRxiv a license to display the preprint in All rights reserved. No reuse allowed without permission.

advanced AD (Supplementary Table 1). The average age was $88.0 \pm 4.3$ years for cognitively healthy individuals and patients with AD. The average MMSE scores were 26.4 \pm 3.6 and $19.8 \pm 5.0$ for cognitively healthy individuals and patients with $\mathrm{AD}$, respectively.

A total of 20 individuals provided post-mortem formalin-fixed paraffin embedded (FFPE) ChP tissue through the Shiley-Marcos UCSD ADRC, including 10 cognitively healthy individuals and 10 patients with advanced AD (Supplementary Table 2). The average age was $84.1 \pm 10.7$ years for cognitively healthy individuals and $84.1 \pm 10.4$ years for patients with AD. The average MMSE scores were $28.3 \pm 2.8$ and $15.9 \pm 8.5$ for cognitively healthy individuals and patients with $\mathrm{AD}$, respectively.

A total of 44 individuals who are part of the Imperial College Parkinson's UK Brain Bank ${ }^{46}$ provided post-mortem stained FFPE ChP slides including 8 healthy individuals, 11 patients with early $\mathrm{AD}(\mathrm{eAD}), 13$ patients with late $\mathrm{AD}(\mathrm{ADD})$ and 12 patients with both $\mathrm{AD}$ and $\mathrm{PD}$ (AD/PD) (Supplementary Table 3). The average age was 73.6 $\pm 9.1,78.5 \pm 11.2,83.2 \pm 9.8$ and $79.9 \pm 6.7$ years for healthy individuals and patients with $\mathrm{eAD}, 1 \mathrm{AD}$ and $\mathrm{AD} / \mathrm{PD}$, respectively. Collection of all samples was approved by the Institutional Review Boards of each participating institution with written consent obtained from all individuals. Research was conducted in accordance with the provisions of the Helsinki Declaration.

\section{Tissue collection}

CSF samples were obtained by lumbar puncture with collection and storage of the samples carried out according to a well-established internationally recognized consensus protocol $1^{43,45,47}$. CSF samples found to be diagnostically unclear or contaminated with blood were excluded from the study. Frozen and formalin fixed paraffin embedded ChP tissue was collected and stored following best practice protocols set forth by the NIH ADRCs. Additional FFPE immune-stained ChP tissue was collected by the Imperial College Parkinson's UK Brain Bank's following standardized protocols ${ }^{46}$. Photographs of postmortem anatomy of ChP were taken at the Imperial College Parkinson's UK Brain Bank.

\section{Cognitive testing}

All study individuals underwent regular comprehensive diagnostic assessment, which consisted in extensive clinical evaluation, blood laboratory tests and brain imaging according to $\mathrm{NIH}$ and other best practice guidelines ${ }^{43,45}$. Clinical evaluation included neurological examination and a battery of neuropsychological tests fulfilling UDS standards. MMSE and the MoCA were used to screen study individuals for cognitive impairment consistent with 
medRxiv preprint doi: https://doi.org/10.1101/2021.07.29.21260696; this version posted August 1, 2021. The copyright holder for this preprint (which was not certified by peer review) is the author/funder, who has granted medRxiv a license to display the preprint in All rights reserved. No reuse allowed without permission.

MCI and dementia. Examinations were performed by board-certified neurologists and clinical psychologists with extensive training and experience in behavioral and cognitive disorders. Clinical phenotypes of MCI and dementia due to AD, PD and ALS were established based on current internationally recognized diagnostic criteria. Lyme disease was diagnosed when individuals demonstrated symptoms and signs of acute polyradiculoneuritis, increased CSF blood count and positive serology for Borrelia burgdorferi.

\section{Pathology}

Frozen and FFPE ChP samples from the UCSD ADRC were scored based on the Braak and Braak staging of the $\mathrm{AD}$ neuropathological changes. Frozen $\mathrm{ChP}$ tissue corresponded to Braak and Braak AD scores of $2.0 \pm 0$ and $5.8 \pm 0.4$ in cognitively healthy individuals and patients with AD, respectively. FFPE ChP tissue corresponded to Braak and Braak AD scores of $1.3 \pm 0.8$ and $5.7 \pm 0.8$ in healthy individuals and patients with $\mathrm{AD}$, respectively. Samples from Imperial College Parkinson's UK Brain Bank were scored for AD (AD), PD (PD) and mixed $\mathrm{AD}$ and $\mathrm{PD}(\mathrm{AD} / \mathrm{PD})$ neuropathology as previously described ${ }^{48}$. Brain pathology of healthy individuals $(\mathrm{H})$ and patients with $\mathrm{eAD}, 1 \mathrm{AD}$ and $\mathrm{AD} / \mathrm{PD}$ corresponded to Braak and Braak $\mathrm{AD}$ stages of $0.6 \pm 0.9,2.6 \pm 0.7,4.5 \pm 0.8$ and $4.3 \pm 1.2$ and to Braak PD stages of $0 \pm 0,0.2 \pm 0.4$, $1.1 \pm 1.5$ and $5.5 \pm 0.5$, respectively. Senile plaques were probed using the primary antibody recognizing amyloid- $\beta$ residues 17 to 24 (4G8, Covance), neurofibrillary changes using an antibody against phosphorylated tau (AT8, Thermo Fisher Scientific) and Lewy pathology using the $\alpha$-synuclein clone 42 antibody (\#610787, BD Transduction Labs). Neurogenerative pathology was assessed by a board-certified pathologist with training and extensive experience in neurodegenerative disorders according to current neuropathological diagnostic guidelines.

\section{ELISArray}

ChP were homogenized using $0.5 \mathrm{~mm}$ glass beads in a Bullet Blender (Next Advance) with two volumes of cold homogenization buffer (20 mM HEPES, $150 \mathrm{mM} \mathrm{NaCl}, 5 \mathrm{mM}$ EDTA, pH 7.0) supplemented with Halt protease and phosphatase inhibitor cocktail (Thermo Fisher). Samples were then sonicated, centrifuged at $17,000 \mathrm{~g}$ for $20 \mathrm{~min}$ at $4^{\circ} \mathrm{C}$ and soluble fractions assessed for their protein content using Pierce BCA protein assay (Thermo Fisher Scientific) and then stored at $-80^{\circ} \mathrm{C}$. Cytokine levels were measured using Multi-Analyte ELISArray using manufacturer's instructions (QIAGEN). In brief, absorbance of the samples was measured at $450 \mathrm{~nm}$ in the Multiskan Go microplate reader (Thermo Fisher Scientific). 
medRxiv preprint doi: https://doi.org/10.1101/2021.07.29.21260696; this version posted August 1, 2021. The copyright holder for this preprint (which was not certified by peer review) is the author/funder, who has granted medRxiv a license to display the preprint in All rights reserved. No reuse allowed without permission.

Concentration of cytokines was determined based on the absorbance values of negative (buffer) and positive controls (standards for all 12 cytokines examined). All measurements were normalized to the total protein content.

\section{Western blots}

Total amount of $40 \mu \mathrm{g}$ of protein per homogenated sample (prepared as for the ELISArray measurements) were separated on 4-20\% SDS-polyacrylamide gels and transferred to PVDF membranes (Bio-Rad Laboratories). After blocking in 5\% BSA in TBS-T, membranes were incubated overnight with primary antibodies against IL-2 (D7A5, Cell Signaling Technology), IL-6 (\#6672, Abcam), IL-10 (\#34843, Abcam), TNFa (\#9739, Abcam) and TGF $\beta 1$ (\#3711, Cell Signaling Technology) at $4^{\circ} \mathrm{C}$. After washing, the membranes were treated with horseradish peroxidase HRP-conjugated secondary antibodies (sc-2357, Santa Cruz Biotechnology) for $1 \mathrm{~h}$ at room temperature. Blots were then developed using enhanced chemiluminescence reagent (Clarity Western ECL substrate, Bio-Rad Laboratories Inc) and visualized using ChemiDoc ${ }^{\mathrm{TM}}$ MP Imaging System with Image Lab Software (Bio-Rad). All samples were run in single blots for each cytokine. Cytokine levels were normalized to $\beta$ actin.

\section{Immunohistochemistry}

FFPE ChP sections were rehydrated with Tissue Clear followed by a $100 \%, 80 \%$ and $50 \%$ ethanol to water gradient. Apart from APOE, all section were then subjected to antigen retrieval with citrate buffer of $\mathrm{pH} 6$ at $95^{\circ} \mathrm{C}$ for 20 (NPC2 and TTR) or 30 (CD3) min or with a Tris-based buffer antigen unmasking solution (Vector Labs) at $95^{\circ} \mathrm{C}$ for $35 \mathrm{~min}(\mathrm{CD} 68)$. Whenever necessary (NPC2, APOE and TTR), the autofluorescence was quenched using TrueBlack Lipofuscin (Biotium). Sections were blocked either for $10 \mathrm{~min}$ with BLOXALL blocking solution (Vector Labs) and 2.5\% horse serum (CD3) or for 30 min with $2.5 \%$ horse serum (CD68) or 10\% with donkey serum (NPC2, APOE and TTR) and then incubated overnight with primary antibodies against NPC2 (1:50, sc-166449, Santa Cruz), APOE (1:100, 178479, Sigma), TTR (1:500, A0002, DAKO), CD3 (1:500, NCL-LCD3-565, Novocastra) or CD68 (1:100, ab955, Abcam). Sections for immunohistochemistry were processed with ImmPRESS Universal Polymer horse anti-mouse/rabbit IgG reagent (Vector Labs) for $30 \mathrm{~min}$, incubated either with NovaRED (CD3, Vector Labs) or ImmPACT DAB 
medRxiv preprint doi: https://doi.org/10.1101/2021.07.29.21260696; this version posted August 1, 2021. The copyright holder for this preprint (which was not certified by peer review) is the author/funder, who has granted medRxiv a license to display the preprint in All rights reserved. No reuse allowed without permission.

EqV solution (CD68, Vector Labs), co-stained with Gill's hematoxylin (Sigma) and last dehydrated through a 50\%,70\% and 100\% water to ethanol gradient followed by Tissue Clear and embedment in Eukitt (Sigma). Haematoxylin eosin-stained ChP sections were provided directly by the UCSD ADRC. Sections for immunofluorescence were incubated with goat anti-mouse 647 (NPC2, 1:500, Life Technologies), donkey anti-goat 546 (APOE, 1:500, Life Technologies) or goat anti-rabbit 546 antibodies (TTR, 1:500, Life Technologies) for $1 \mathrm{~h}$ at room temperature, co-stained with DAPI for $20 \mathrm{~min}$ and mounted using Mowiol (Sigma). Sections stained with secondary antibodies only were used as negative controls.

\section{Microscopy and image processing}

Stained at FFPE ChP sections were imaged using AxioScan.Z1 scanner microscope (Zeiss) at a magnification of $10 \times$. Acquired images were processed and analyzed using the Image Pro Premier 3D software (Media Cybernetics). To examine the distribution of NPC2, APOE and TTR in the ChP, the slides were imaged with a $63 \times$ oil-immersion objective using a confocal laser scanning microscope (Zeiss). Acquired images were then processed and analysed using ImageJ software.

\section{Quantitative histology}

Hematoxylin eosin-stained ChP sections were examined for pathological changes by a boardcertified pathologist with training and extensive experience in neurodegenerative disorders. Inflammatory cells, visualized either by hematoxylin eosin staining or by an anti-CD-68 antibody, were quantified on 6 high-magnification ChP images per section. Anti-CD-3 antibody recognized individual inflamatory cells on rare occasions in $\mathrm{H}$ and AD ChP. As a result, we did not pursue formal quantification of inflammatory cells recognized by the antiCD-3 antibody. To measure NPC2, APOE and TTR total mean intensities, a grid of $500 \times 500$ pixel squares was placed over each ChP image. 30 grid squares were randomly selected in order to sample NPC2, APOE and TTR total mean intensities across the entire ChP. 3 rectangular regions of interest were examined per each grid square for a total of 90 regions of interest per image. The placement of the regions of interest was performed to best fit epithelium and stroma. Mean intensities of the regions of interest were calculated using Image Pro Premier 3D software (Media Cybernetics). To examine distribution of NCP2, APOE and TTR within the $\mathrm{ChP}$, the slides were imaged with a $63 \times$ oil-immersion objective using a confocal laser scanning microscope (Zeiss). 1-4 ChP grape-like structures in 3 independent 
medRxiv preprint doi: https://doi.org/10.1101/2021.07.29.21260696; this version posted August 1, 2021. The copyright holder for this preprint (which was not certified by peer review) is the author/funder, who has granted medRxiv a license to display the preprint in All rights reserved. No reuse allowed without permission.

fields of view were sampled per each slide based on the ChP morphology for detailed analysis of the immunoreactivity of the choroid epithelium and stroma.

\section{Mass spectrometry proteomics of the CSF}

CSF samples were analysed using two independent mass spectrometry proteomic protocols:

Protocol A: Samples were analyzed by LC-MS/MS using an UltiMate 3000 RSLCnano system (Thermo Fisher Scientific) coupled via an EASY-spray ion source (Thermo Fisher Scientific) to an Orbitrap Elite mass spectrometer (Thermo Fisher Scientific). Purified peptides were separated on $50 \mathrm{~cm}$ EASY-Spray column $(75 \mu \mathrm{m}$ ID, PepMap C18, $2 \mu \mathrm{m}$ particles, $100 \AA$ pore size; Thermo Fisher Scientific). For each LC-MS/MS analysis, 3 technical replicates of $500 \mathrm{ng}$ of tryptic peptides per sample were used for $165 \mathrm{~min}$ runs. For the first $5 \mathrm{~min}$, peptides were loaded onto a $2 \mathrm{~cm}$ trap column (Acclaim PepMap 100, $100 \mu \mathrm{m}$ ID, C18, $5 \mu \mathrm{m}$ particles, $100 \AA$ pore size; Thermo Fisher Scientific) in loading buffer (98.9\%/1\%/0.1\%, v/v/v, water/acetonitrile/formic acid) at a flow rate of $6 \mu 1 / \mathrm{min}$. Peptides were then added to buffer A $(99.9 \% / 0.1 \%, v / v$, water/formic) and eluted from the EASYSpray column with a linear 120 min gradient of $2 \%-35 \%$ of buffer B $(99.9 \% / 0.1 \%$, v/v, acetonitrile/formic acid), followed by a $5 \mathrm{~min} 90 \% \mathrm{~B}$ wash at a flow rate $300 \mathrm{nl} / \mathrm{min}$. EASYSpray column temperature was kept at $35^{\circ} \mathrm{C}$. Mass spectrometry data were acquired with a Top12 data-dependent mode in the Orbitrap with a resolution of 120,000 at $\mathrm{m} / \mathrm{z} 400$, AGC $1 \mathrm{E} 6$ in the $300-1700 \mathrm{~m} / \mathrm{z}$ range with a maximum injection time of $35 \mathrm{~ms}$. The $2 \mathrm{~m} / \mathrm{z}$ isolation window was used for MS/MS scans. Fragmentation of precursor ions was performed by CID with a normalized collision energy of 35 . MS/MS data were acquired in ion trap with ion target value of 1E4 and maximum injection time of $100 \mathrm{~ms}$. Dynamic exclusion was set to 70 $\mathrm{s}$ to avoid repeated sequencing of identical peptides.

Protocol B: Samples were analyzed by LC-MS/MS using an UltiMate 3000 RSLCnano system coupled to an Orbitrap Fusion Lumos tribrid mass spectrometer (both Thermo Fisher Scientific). $1 \mu \mathrm{g}$ of tryptic peptides per sample (1 technical replicate per sample) was reconstituted in $5 \mu 1$ of the solvent (98\% water, $2 \%$ acetonitrile, $0.1 \%$ formic acid) and loaded on a $15 \mathrm{~cm}$ C18 Easy Spray column ( $2 \mu \mathrm{m}$ particle size, $50 \mu \mathrm{m}$ ID) kept at $45^{\circ} \mathrm{C}$. Peptides were then separated using a binary solvent system (Solvent A: Water, $0.1 \%$ formic acid; Solvent B: Acetonitrile, $0.1 \%$ formic acid) operating at a flow rate of $300 \mathrm{nl} / \mathrm{min}$ with the following $120 \mathrm{~min}$ gradient: $2 \%$ to $19 \% \mathrm{~B}$ in $80 \mathrm{~min}, 19 \%$ to $30 \% \mathrm{~B}$ in $20 \mathrm{~min}, 30$ to $98 \% \mathrm{~B}$ in $5 \mathrm{~min}$, plateau at $98 \%$ for $2 \mathrm{~min}$, return to initial conditions in $1 \mathrm{~min}$ and equilibration for 
medRxiv preprint doi: https://doi.org/10.1101/2021.07.29.21260696; this version posted August 1, 2021. The copyright holder for this

preprint (which was not certified by peer review) is the author/funder, who has granted medRxiv a license to display the preprint in

All rights reserved. No reuse allowed without permission.

12 min. MS data were acquired using Xcalibur v4.1 (Thermo Fisher Scientific) in top-speed data dependent mode with MS1 in the Orbitrap (Resolution: 120,000, AGC: 2E5) followed by HCD $(35 \% \mathrm{NCE})$ fragmentation of most abundant precursor ions with a charge state between 2-6 and detection in the Orbitrap (Resolution: 30,000, AGC: 5E4). Quadrupole isolation was enabled and dynamic exclusion was set to $60 \mathrm{~s}$.

\section{CSF proteomic data processing}

The raw data were analysed using MaxQuant software (version 1.5.6.5) by Andromeda search engine. Proteins were identified by searching MS and MS/MS data against the human proteome (UniProtKB, UP000005640, January 2017) and the common contaminants database. Carbamidomethylation of cysteines was set as a fixed modification. N-terminal acetylation and oxidation of methionines were set as variable modification. Trypsin was set as protease and maximum of two missed cleavages were allowed in the database search. Peptide identification was performed with an allowed initial precursor mass deviation up to $7 \mathrm{ppm}$ (Orbitrap) and an allowed fragment mass deviation of $0.5 \mathrm{Da}$ (ion trap). The "matching between runs" option was enabled to match identifications across samples within a time window od $20 \mathrm{~s}$ of the aligned retention times. The false discovery rate was set to 0.01 for both proteins and peptides with a minimum length of seven amino acids. LFQ was performed with a minimum ratio count of 2 . Protein abundances were calculated on the basis of summed peptide intensities of "unique and razor" peptide.

For bioinformatic and statistical analysis, the MaxQuant output file (ProteinGroups.txt) was uploaded to the Perseus software (version 1.6.1.1). Proteins idenified by site and matching to the reverse database were excluded. Data was transformed to a logarithmic scale $(\log 2(\mathrm{x}))$ and then normalized (Z-score). Samples were manually annotated based on technical and clinical conditions (AD, MCI, ALS, LYME). Technical replicates were averaged. Proteins were included into the analyses only if present in at least $50 \%$ of the samples in every condition. Differential expression was tested using $t$-test with permutation-based FDR calculation $(\mathrm{p}<0.05)$. Volcano plot was used to visualize the results of the $t$-test. Clustvis 2.0 webtool was used for cluster analyses and Venn diagrams. g:Profiler was used for the functional enrichment analysis of the significant protein changes. 
medRxiv preprint doi: https://doi.org/10.1101/2021.07.29.21260696; this version posted August 1, 2021. The copyright holder for this preprint (which was not certified by peer review) is the author/funder, who has granted medRxiv a license to display the preprint in All rights reserved. No reuse allowed without permission.

TMT-based quantitative discovery mode CSF preteomics dataset from a previously reported analysis of a well-established cohort of 297 individuals ${ }^{30,31}$ was reanalyzed in this study for age-stratified differences (Fig. 2a-5, Fig. 3a).

\section{Processing of ChP tissue for mass spectrometry assays and global lipid analysis}

ChP samples were homogenized using BeadBlaster 24 (Benchmark Scientific Inc.), lyophilized, resuspended in $100 \mu \mathrm{l}$ of ultrapure water and the total protein concentrations determined using the BCA kit (Thermo Fisher Scientific). Next, $360 \mu 1$ of isopropanol were added to each sample, which was vortexed, sonicated and centrifuged at room temperature. $400 \mu 1$ of the supernatant were then removed and diluted 5 -fold in $10 \%$ isopropanol for the ganglioside and other assays (lipid extract). Remaining pellets were dried at $37^{\circ} \mathrm{C}$ (Savant SDP121 P, SpeedVac, Thermo Fisher Scientific), reconstituted using glass beads in $100 \mu 1$ of AmBic buffer $(50 \mathrm{mM})$ with SDC $(5 \mathrm{mg} / \mathrm{ml})$, homogenized, vortexed and sonicated (protein extract). $20 \mu \mathrm{g}$ of total protein per sample were next reduced $\left(20 \mathrm{mM}\right.$ DTT; $\left.10 \mathrm{~min} ; 95{ }^{\circ} \mathrm{C}\right)$ and alkylated (40 mM IAA; $30 \mathrm{~min}$; room temperature in the dark). Synthetic isotopically labeled standard peptides containing an enzymatically cleavable tag at C-terminus (TQL, JPT) were added to control for the variance in trypsin digestion. Trypsin was added to the samples in the 1:40 ratio (enzyme: total protein content, w/w), and the samples gently shaken overnight at $37{ }^{\circ} \mathrm{C}$. The digestion was quenched by adding $200 \mu 1$ of $2 \%$ formic acid. Solidphase extraction (SPE) was carried out on a mixed-mode cartridge according to the manufacturer's instructions (Oasis Prime HLB).

\section{Validation of mass spectrometry targets}

Gangliosides were quantified using selected reaction monitoring (SRM) assays in lipid extracts, which were internally standardized with $1.5 \mu \mathrm{M}$ and $0.15 \mu \mathrm{M}$ of isotopically labeled GM1 and GM3, respectively (Extended Data Figure 7). Proteins were also analyzed using SRM assays for proteotypic peptides as protein surrogates. Tentative identifications of proteotypic peptides detected in CP and concordant with the Skyline iRT Retention Time Prediction algorithm were validated using their isotopically-labeled analogs (Extended Data Figure 5). Only proteotypic peptides with the SRM signatures and retention times matching corresponding isotopically-labeled peptide standard were accepted as correct identifications. The peak area of the proteotypic peptide was normalized to the average peak area of 5 
medRxiv preprint doi: https://doi.org/10.1101/2021.07.29.21260696; this version posted August 1, 2021. The copyright holder for this preprint (which was not certified by peer review) is the author/funder, who has granted medRxiv a license to display the preprint in All rights reserved. No reuse allowed without permission.

isotopically-labeled RT indices and the ratio multiplied by the concentration of RT indices to calculate relative protein concentrations using $\mathrm{c}($ light $)=$ peak area (light)/peak area (average heavy) x concentration (average heavy).

\section{Mass spectrometry quantitative protein assays}

Dried solid-phase extracts of $\mathrm{ChP}$ digests were reconstituted in $13.3 \mu 1$ of $5 \%$ acetonitrile with $0.1 \%$ formic acid. Samples were analyzed using ESI-UHPLC-SRM mass spectrometry on a triple quadrupole mass analyzer (1290 Infinity II and 6495B, Agilent) in positive ion detection mode. A volume of $2 \mu \mathrm{l}$ was injected into the Peptide CSH C18 column $(1.7 \mu \mathrm{m}$, $2.1 \mathrm{~mm} \times 100 \mathrm{~mm}$, Waters Corporation). The mobile phase at a flow rate of $0.3 \mathrm{ml} / \mathrm{min}$ consisted of buffer A ( $0.1 \%$ formic acid) and buffer B $(0.1 \%$ formic acid in $95 \% \mathrm{ACN})$. Linear gradient elution was performed as follows: initial 5\% B; 25 min $30 \%$ B; 25.5 min 95 $\% \mathrm{~B} ; 30 \mathrm{~min} 95 \% \mathrm{~B}$ and from 31 to $35 \mathrm{~min}$ with $5 \% \mathrm{~B}$. The electrospray ionization source temperature was $200{ }^{\circ} \mathrm{C}$ and voltage $3.5 \mathrm{kV}$. SRM assays were scheduled for $2 \mathrm{~min} \mathrm{RT}$ windows around peptide RT. SRM transitions (3-5 per proteotypic peptide) and optimal collision energies were obtained using the SRMAtlas database (www.srmatlas.org). Data were processed in Skyline (Version 19.1.0.193, MacCoss Lab).

\section{Mass spectrometry ganglioside assays}

Gangliosides in lipid extracts of ChP were examined using both ESI-UHPLC-SRM positive and negative ion detection modes. Diluted lipid extracts were injected into a C18 column $\left(\mathrm{CSH}, 50 \times 2.1 \mathrm{~mm}, 1.7 \mu \mathrm{m}\right.$, Waters Corporation) thermostated at $40^{\circ} \mathrm{C}$. The mobile phase of buffer A (0.5 mM ammonium fluoride) and buffer B (methanol: isopropanol (50:50 v/v) at the flow rate of $0.3 \mathrm{~mL} / \mathrm{min}$ was used in positive ion mode. The gradient elution program (17.1 min) was: $0 \min 30 \% \mathrm{~B} ; 2 \min 70 \% \mathrm{~B} ; 9 \min 95 \% \mathrm{~B} ; 13 \min 95 \% \mathrm{~B} ; 13.3 \min 5 \% \mathrm{~B} ; 14.3$ $\min 5 \% \mathrm{~B} ; 14.5 \min 30 \% \mathrm{~B} ; 17.1 \mathrm{~min} 30 \% \mathrm{~B}$. The mobile phase of buffer A $(0.5 \mathrm{mM}$ ammonium fluoride and $10 \mathrm{mM}$ ammonium acetate) and buffer $\mathrm{B}$ (acetonitrile: isopropanol $(50: 50 ; v / v)$ at a flow rate of $0.3 \mathrm{~min} \mathrm{~mL} / \mathrm{min}$ was used in negative ion mode. The gradient elution program (19.1 min) was: $0 \min 10 \% \mathrm{~B} ; 4 \min 85 \% \mathrm{~B} ; 6.2 \min 95 \% \mathrm{~B} ; 10.2$ 95\% B; $10.410 \% \mathrm{~B} ; 14.495 \% \mathrm{~B} ; 16.295 \% \mathrm{~B} ; 16.410 \% \mathrm{~B} ; 19.1 \% \mathrm{~B}$. The electrospray ionization source capillary voltage was $3500 \mathrm{~V}$ and $3000 \mathrm{~V}$ in positive and negative ion modes, respectively. The gas flow rate was $16 \mathrm{~L} / \mathrm{min}$ and $14 \mathrm{~L} / \mathrm{min}$ at $190^{\circ} \mathrm{C}$, sheath gas pressure 20 PSI and $25 \mathrm{PSI}$ at $350^{\circ} \mathrm{C}$ and nozzle voltage $1300 \mathrm{~V}$ and $1500 \mathrm{~V}$ in positive and negative ion detection modes, respectively. Data were processed in Skyline (v19.1.0.193, MacCoss Lab). 
medRxiv preprint doi: https://doi.org/10.1101/2021.07.29.21260696; this version posted August 1, 2021. The copyright holder for this preprint (which was not certified by peer review) is the author/funder, who has granted medRxiv a license to display the preprint in All rights reserved. No reuse allowed without permission.

Gangliosides were quantified with the stable isotope-labeled GM3 using appropriate response factors (except for GM1 quantified with the stable isotope-labeled GM1). Ganglioside content was reported in $\mathrm{ng} / \mathrm{mg}$ of $\mathrm{CP}$ tissue dry weight.

\section{Mass spectrometry lipid analysis}

Orbitrap Fusion (Thermo Fisher Scientific) and UHPLC (Nexera X2, LC-30AD, Shimadzu) with identical C18 column (CSH, $50 \times 2.1 \mathrm{~mm}, 1.7 \mu \mathrm{m}$, Waters Corporation) thermostated at $40^{\circ} \mathrm{C}$ and gradient elution program as specified for ganglioside assays in the positive ion mode were used to measure lipids. The electrospray ionization in positive and negative ion modes with capillary voltages of $4000 \mathrm{~V}$ and $3500 \mathrm{~V}$, respectively, were used to acquire fullscan spectra. Sweep gas flow rate was 2 arbitrary units, sheath gas flow rate 30, auxiliary gas flow rate 5 and ion transfer tube and vaporizer temperatures $350{ }^{\circ} \mathrm{C}$ and $300{ }^{\circ} \mathrm{C}$, respectively. The resolving power was 120000 at $400 \mathrm{~m} / \mathrm{z}$, maximum injection time $5 \mathrm{~ms}$, ACG 4.0x10 and lenses RF level 50\%. Data were acquired in centroid mode and converted to mzML format through MS Convert from ProteoWizard and analyzed through XCMS using the centWave algorithm. The XCMS output feature $(\mathrm{m} / \mathrm{z})$ list was submitted to the CEU mediator (Batch Advanced Search) to return database hits. The following CEU mediator settings were used: a) mass accuracy (tolerance) was set at $3 \mathrm{ppm}$, b) selected databases included LipidMaps, HMDB, Kegg and Metlin, c) respective ionization mode, d) input mass was $\mathrm{m} / \mathrm{z}$ mass (instead of neutral mass) and e) in case of multiple hits per $\mathrm{m} / \mathrm{z}$, the tentative identification of adducts $\mathrm{M}+\mathrm{H}+$ was manually assigned based on similar retention time with a lipid from the same group, ppm error and available LipidMaps annotation. Features matching to multiple annotations with similar RT, ppm, and database availability remained unidentified. The most abundant lipid species were manually matched with the literature to verify tentative identifications further.

\section{Cholesterol spectrophotometric assay}

Cholesterol was extracted from $1 \mathrm{mg}$ of dry ChP tissue by adding $100 \mathrm{ul}$ of Chloroform: Isopropanol. Samples were vortexed, sonicated and centrifuged. The ultra-filtrate was transferred to a separate vial and air-dried at $50^{\circ} \mathrm{C}$ to remove chloroform and placed in a vacuum concentrator centrifuge to remove remaining isopropanol. Cholesterol was quantified using a colorimetric assay based on the manufacturer's instructions (MAK043, SigmaAldrich, USA). 
medRxiv preprint doi: https://doi.org/10.1101/2021.07.29.21260696; this version posted August 1, 2021. The copyright holder for this preprint (which was not certified by peer review) is the author/funder, who has granted medRxiv a license to display the preprint in All rights reserved. No reuse allowed without permission.

\section{In vivo brain MRI imaging}

T1-weighted 3-dimensional high-resolution MRI images were acquired using magnetizationprepared rapid gradient echo (MP-RAGE, TR/TE/TI $=2000 / 3.08 / 1100 \mathrm{~ms}$, flip angle $=15^{\circ}$, $1.0 \mathrm{~mm}$ slice thickness) and fast spoiled gradient echo (FSPGR, TR/TE/TI = 7.26/2.99/400 $\mathrm{ms}$, flip angle $=11^{\circ}, 1.2 \mathrm{~mm}$ slice thickness) pulse sequences using 1.5 T (Siemens Avanto) and 3.0 T scanners (GE Signa HDxt) in the Czech Brain Aging Study and the Argentina Alzheimer's Disease Neuroimaging Initiative, respectively. All images were first visually inspected to ensure appropriate data quality and to exclude participants with clinically relevant brain pathology that could interfere with cognitive functioning and testing such as subdural hematoma, cortical infarct, tumour or hydrocephalus. To correct for differences in head size, all volumetric measurements were normalized to the total intracranial volume.

\section{MRI intensity measurements}

Based on FreeSurfer wrapped in R, all segmented regions of interest and their masks were exported, including $\mathrm{ChP}$ intensities. Since raw intensities of $\mathrm{ChP}$ preclude their direct use in statistical analysis, we normalized raw intensity of ChP to CSF considering MRI signal of the CSF does not significantly change between $\mathrm{H}$ and AD. The CSF strip algorithm was developed based on the white strip algorithm ${ }^{49}$.

\section{MRI volumetry measurements}

Measurements of cortical, hippocampal and ChP volumes were performed using FreeSurfer automated algorithm version v5.3 (http://surfer.nmr.mgh.harvard.edu/) as previously reported $^{50-52}$. Subset of MRI brain images were further evaluated using 3D reconstructions. Automatic segmentation of FreeSurfer wrapped in R was used to obtain segmentation masks for all regions of interest. All T1-weighted images were registered to a common MNI305 template using linear (affine) and ANTs (SyN) spatial normalization algorithms ${ }^{53}$ and symmetric image spatial normalization $(\mathrm{SyN})$ algorithm with cross-correlation as similarity metric through Advanced Normalization Tools (ANTSs). Registered masks of structures of interest were then averaged to produce structure template used for visualizations. The isosurfaces of the template were extracted using marching cube algorithm. Inverse warp field from SyN were then decomposed by Principal Component Analysis and the first principal component projected back to shape space and averaged across groups. Vector fields of differences between $\mathrm{H}$ and $\mathrm{AD}$ regions of interest were orthogonally projected to normal 
medRxiv preprint doi: https://doi.org/10.1101/2021.07.29.21260696; this version posted August 1, 2021. The copyright holder for this

preprint (which was not certified by peer review) is the author/funder, who has granted medRxiv a license to display the preprint in

All rights reserved. No reuse allowed without permission.

vector field from the average template, converted from mean to percentage change with normalization by centroid size and then used for coloring of the average template. To examine 3-dimensional differences between $\mathrm{H}$ and $\mathrm{AD} \mathrm{ChP}$ in shape, $\mathrm{ChP}$ were represented with 4246 mesh points, the percentage change was calculated as (mean AD minus mean $\mathrm{H}$ ) divided by mean $\mathrm{H}$ and multiplied by 100 , where positive sign reflects larger areas in $\mathrm{AD}$ and scaling is done with respect to $\mathrm{H}$ mean.

\section{Manual MRI tracing}

T1-weighted brain images underwent quality assessment, including dicom format check and check for imaging artefacts. ChP segmentation was performed manually by two trained readers with significant background and experience with MRI imaging. Segmentation was performed using Slicer (www.slicer.org) on a slice per slice basis with a paintbrush of 0.5 $\mathrm{mm}$. Segmentation started at the top of the brain in the axial orientation with the reader moving down the brain to detect the first slice showing the contour of the ChP and then continuing consecutively through all the slices showing $\mathrm{ChP}$. Once the region of interest was fully delineated, potential over- and under-segmented areas were checked in coronal orientation and segmentations corrected whenever necessary. Particular attention was given to brain regions where segmentation of the ChP may be difficult. First, ChP can be present in areas around the anterior pillars of the fornix and beneath there, it needs to be first distinguished from vascular structures and then segmented correctly. Second, signal from the hippocampal commissure and crura of the fornix, which appear as continuity of the ChP, was excluded from the segmentation. Particular attention was given to segment the thin lining of the $\mathrm{ChP}$ in the temporal horn of the lateral ventricles. After slice-to-slice manual segmentation of the $\mathrm{ChP}$, the $3 \mathrm{D}$ volume rendering was performed to test for appropriate spatial appearance of $\mathrm{ChP}$ in line with the expected anatomy. Since ChP segmentations were performed voxelwise, generating labelled maps, the volumes were calculated as the sum of all voxels of the labeled maps multiplied by voxel size. Considering small size of ChP the obtained volumes were not normalized.

\section{Statistics}

All statistical analyses were performed using commercially available softwares (R, Prism, Excel, SPSS and SAS). Mass spectrometry proteomics of the CSF and brain imaging analyses were performed using R (v.4.1.0, R Core Team 2020. R: A language and environment for 
medRxiv preprint doi: https://doi.org/10.1101/2021.07.29.21260696; this version posted August 1, 2021. The copyright holder for this preprint (which was not certified by peer review) is the author/funder, who has granted medRxiv a license to display the preprint in All rights reserved. No reuse allowed without permission.

statistical computing. $\mathrm{R}$ Foundation for Statistical Computing, Vienna, Austria). RColorBrewer, igraph, ggraph and ggplot2 packages were used for differential CSF protein expression analyses. For brain imaging analyses we used R packages Whitestripe, FreeSurfer, NeuroBase, fslr, fsbrain, misc3d, rgl and ggplot2. All values are expressed as mean \pm s.e.m. Differences in means between $\mathrm{H}$ and $\mathrm{AD}$ were analysed using two-sample $t$-test at a significance $\alpha$ level of 0.05 unless otherwise specified. All tested hypotheses were two-sided $\left(\mathrm{H}_{0}\right.$ : equality of means vs $\mathrm{H}_{1}$ : means are not equal). Missing values were not imputed. Differences in the shape of $\mathrm{ChP}$ between $\mathrm{H}$ and $\mathrm{AD}$ were assessed using a mesh point-bypoint two-sample $t$-test with differences in coronal, sagittal and axial planes projected to $\mathrm{H}$ with $t$-statistics and p-values at a significance $\alpha$ level of 0.05 presented as a coloured statistical parameter map. No statistical analyses were performed to predetermine sample size.

\section{Reporting summary}

Further information on research design is available ... Summary linked to this paper.

\section{Data availability}

All mass spectrometry data have been deposited online (PRIDE ID). CSF data for the cohort of 297 individuals ${ }^{30,31}$ are available online at https://www.synapse.org/Consensus.

\section{Acknowledgements}

Authors wish to acknowledge Sebastian Novotny and other members of the Stokin Lab, Antonio Pompeiano and Michal Šitina from the Biostatistics core facility of the International Clinical Research Center of St. Anne's University Hospital, Kateřina Coufalikova from the RECETOX Centre of the Faculty of Sciences, Masaryk University, Jeffrey Metcalf and Sara Shuldberg from the Rissman Lab, participants, families and all others involved in the Czech Brain Aging Study, Argentina Alzheimer's Disease Neuroimaging Initiative, Shiley-Marcos ADRC at the UCSD, Imperial College Parkinson's UK Brain Bank, Institute of Molecular and Translational Medicine and the ALS Tissue Bank and Target ALS Postmortem Core, Barrow Neurological Institute, for providing human data and samples. We thank PrecisionMed for their guidance regarding human tissues. This study was supported by the European Regional Development Funds No. CZ.02.1.01/0.0/0.0/16_019/0000868 ENOCH grant (S.B., J.D., G.F., J.F., M.H., J.H., S.K. and G.B.S.), Research Infrastructure RECETOX RI grant (No LM2018121) financed by the Ministry of Education, Youth and Sports, and Operational Programme Research, Development and Innovation - CZ.02.1.01/0.0/0.0/17_043/0009632 
medRxiv preprint doi: https://doi.org/10.1101/2021.07.29.21260696; this version posted August 1, 2021. The copyright holder for this preprint (which was not certified by peer review) is the author/funder, who has granted medRxiv a license to display the preprint in All rights reserved. No reuse allowed without permission.

CETOCOEN EXCELLENCE project, and the HORIZON 2020 No. 857560 (J.D., G.B.S. and Z.S.), the Czech Ministry of Health grants NV 18-04-00346 (Z.N.), NV 18-04-00455 and 00064203 (J.H.), NV19-08-00472 (Z.S. and K.S.), the No. CZ.02.1.01/0.0/0.0/16_026/0008451 INBIO grant (J.D.), NIH grant P30 AGO62429 (R.A.R.), the Barrow Neurological Foundation and the Fein Foundation (R.B.), the research infrastructure LM2018121 RECETOX grant (Z.S.), the Grant Agency of the Masaryk University No. MUNI/G/1131/2017 GAMU (Z.S.) and MUNI/A/1615/2020 (S.K.) grants, the National Cancer Institute of the NIH grant No. P30CA033572 (P.P.), the NIA U01 grant U01AG061357 (E.B.D. and N.T.S.) and the Institutional Support of Excellence 2. LF UK grant 6990332 (J.H.).

\section{Author Information}

\section{Affiliations}

Internatonal Clinical Research Centre, St. Anne's University Hospital, Brno, Czech Republic Maria Čarna, Isaac G. Onyango, Stanislav Katina, Zuzana Nedelska, Valentina Lacovich, Martin Vyhnalek, Kateřina Texlova, Michal Šitina, Hana Markova, Jan Laczo, Kateřina Sheardova, Jan Frič, Giancarlo Forte, Silvie Belaškova, Jiři Damborsky, Jakub Hort, Gorazd B. Stokin

Institute of Mathematics and Statistics, Masaryk University, Brno, Czech Republic

Stanislav Katina, Mojmir Vinkler

Institute for Molecular and Translational Medicine, Faculty of Medicine and Dentistry, Palacky University Olomouc, Olomouc, Czech Republic

Dušan Holub, Marian Hajduch

RECETOX Centre, Faculty of Sciences, Masaryk University, Brno Czech Republic

Marketa Nezvedova, Durga Jha, Kateřina Coufalikova, Jiři Damborsky, Zdeněk Spačil

Memory Clinic, Department of Neurology, $2^{\text {nd }}$ Faculty of Medicine, Charles University and Motol University Hospital, Prague, Czech Republic

Zuzana Nedelska, Martin Vyhnalek, Hana Markova, Jan Laczo, Jakub Hort

Icometrix, Leuven, Belgium

Thijs Vande Vyvere, Ruben Houbrechts

Collaborative Center for Translational Mass Spectrometry, Translational Genomics Research Institute, Phoenix, Arizona, USA

Krystine Garcia-Mansfield, Ritin Sharma, Victoria David-Dirgo, Patrick Pirrotte 
medRxiv preprint doi: https://doi.org/10.1101/2021.07.29.21260696; this version posted August 1 , 2021. The copyright holder for this preprint (which was not certified by peer review) is the author/funder, who has granted medRxiv a license to display the preprint in All rights reserved. No reuse allowed without permission.

Mass Spectrometry \& Proteomics Core Facility, City of Hope Comprehensive Cancer Center, Duarte, USA

Patrick Pirrotte

FLENI, Buenos Aires, Argentina

Lucia Pertierra, Hernan Chaves, Gustavo Sevlever

Department of Neurobiology, Barrow Neurological Institute, Phoenix, Arizona, USA

Nadine Bakkar, Robert Bowser

$1^{\text {st }}$ Department of Neurology, St. Anne's University Hospital and Faculty of Medicine, Masaryk University, Brno, Czech Republic

Kateřina Sheardova

Institute of Hematology and Blood Transfusion, Prague, Czech Republic

Jan Frič

Department of Neurology, Faculty of Medicine and Dentistry, Palacky University Olomouc and Research and Science Department, University Hospital Olomouc, Olomouc, Czech Republic

Petr Kaňovsky

Center for Neurodegenerative Disease, Goizueta Alzheimer's Disease Research Center and Departments of Biochemistry and Neurology, Emory University School of Medicine, Atlanta, USA

Nicholas T. Seyfried, Eric B. Dammer

Department of Neurosciences, University of California San Diego, La Jolla, USA

Robert A. Rissman

Center for Neurologic Study, La Jolla, California, USA

Richard A. Smith

Department of Cellular Pathology, Imperial College Healthcare NHS Trust, London, UK

Clara Limbäck-Stokin

Imperial College London, Faculty of Medicine, London, UK

Clara Limbäck-Stokin

Division of Neurology, University Medical Centre, Ljubljana, Slovenia

Gorazd B. Stokin

Translational Aging and Neuroscience Program, Mayo Clinic, Rochester, USA

Gorazd B. Stokin

\section{Contributions}


medRxiv preprint doi: https://doi.org/10.1101/2021.07.29.21260696; this version posted August 1, 2021. The copyright holder for this preprint (which was not certified by peer review) is the author/funder, who has granted medRxiv a license to display the preprint in All rights reserved. No reuse allowed without permission.

G.B.S. designed and planned the study, M. Č. and G.B.S. analysed all the data and wrote the manuscript, I.G.O. performed ChP cytokine experiments and analysis, C.L.-S. and R.A.R. provided ChP samples, C.L.-S. performed all the ChP neuropathological experiments and analysis, N.B., R.B., J.H., M.H. and K.S. contributed CSF samples, V.D.-D., K.G.-M., D.H., M.H., R.S., and P.P. performed all the CSF mass spectrometry experiments, J.D., D.J., M.N. and Z.S. performed all the ChP mass spectrometry and other lipid experiments, V.L. and K.T. performed ChP immunohistochemistry and analysis, H.C., J.H., Z.N., L.P. H.M., G.S. and M.V. were involved in the acquisition and analysis of MRI images, S.K. and M.V. performed MRI image and shape programming and analysis, including intensities and volumes, R.H. and T.V.V. and performed manual ChP measurements, M. Č., E.B.D. and D.H. performed all the bioinformatics assessments and analysis, S.B., J.D. and M. ̌̆. performed biostatistical analysis, R.B., S.B., J.D., G.F., J.F., J.H., P.P., C.L.-S., N.T.S., G.S., Z.S. and R.A.S. provided continuous input during experiments and data analysis.

\section{Corresponding author}

Correspondence to Gorazd B. Stokin E-mail: gbstokin@alumni.ucsd.edu

\section{Ethics declaration}

\section{Competing interests}

No competing interests.

\section{Additional information}

Publisher's note 
medRxiv preprint doi: https://doi.org/10.1101/2021.07.29.21260696; this version posted August 1, 2021. The copyright holder for this

\section{Extended data figures and tables}

Extended Data Figure 1 - No morphological changes in the $\mathrm{ChP}$ from $\mathrm{H}$ and $\mathrm{AD}$ a, Representative image of haematoxylin eosin-stained $\mathrm{ChP}$ consisting of peripheral vasculature rich stroma lined by epithelium. b, Percentage of ChP from $H(n=10)$ and AD $(n=10)$ showing epithelial atrophy, stromal fibrosis, vessel thickening, cystic dilations and calcifications. 1 technical replicate \pm s.e.m.; two-sample $t$-test $(\mathrm{p} \leq 0.05)$. c, Average number of inflammatory cells in haematoxylin eosin-stained $\mathrm{ChP}$ from $\mathrm{H}(\mathrm{n}=10)$ and $\mathrm{AD}(\mathrm{n}=10) \mathrm{ChP}$. Mean number of inflammatory cells per 5 high power microscopy fields per section \pm s.e.m.; two-sample $t$-test $(\mathrm{p} \leq 0.05)$. d, Representative low and high magnification images of $\mathrm{ChP}$ from $\mathrm{H}$ and $\mathrm{AD}$ stained with an anti-CD68 antibody (asterisks denote anti-CD68 antibody labelled cells in brown). e, Average number of anti-CD68 antibody labelled cells per ChP section in $\mathrm{H}(\mathrm{n}=8)$ and $\mathrm{AD}(\mathrm{n}=10) \mathrm{ChP}$. Mean number of inflammatory cells per 10 high power microscopy fields per section \pm s.e.m.; two-sample $t$-test $(\mathrm{p} \leq 0.05)$. e, Representative low and high magnification image of a $\mathrm{ChP}$ from $\mathrm{H}$ stained with an anti-CD3 antibody (asterisk denotes anti-CD3 antibody labelled cell in red).

Extended Data Figure 2 - Lack of AD pathology in the ChP in AD Percentage of ChP from $\mathrm{H}(\mathrm{n}=8)$, early $\mathrm{AD}(\mathrm{eAD}, \mathrm{n}=11)$, late $\mathrm{AD}(1 \mathrm{AD}, \mathrm{n}=13)$ and $\mathrm{AD}$ with Parkinson's disease $(\mathrm{AD} / \mathrm{PD}, \mathrm{n}=12)$ showing: epithelial atrophy, a, stromal fibrosis, $\mathbf{b}$, vessel thickening, $\mathbf{c}$, and calcifications, d. 1 technical replicate \pm s.e.m.; two-sample $t$-test $(\mathrm{p} \leq 0.05)$. Anti-amyloid- $\beta$ antibody showing senile plaques in the hippocampus of $\mathrm{AD}$ (positive control), e, but no senile plaques in the $\mathrm{ChP}$ from $\mathrm{H}, \mathbf{f}, \mathrm{eAD}, \mathbf{g}, \mathrm{AD}, \mathbf{h}$ or $\mathrm{AD} / \mathrm{PD}, \mathbf{i}$ (magnification bar $100 \mu$ ). Antiphospho-tau antibody showing neurofibrillary changes in the hippocampus of AD (positive control), $\mathbf{j}$, but no phospho-tau-immunoreactive deposits in the ChP from $\mathrm{H}, \mathbf{k}, \mathrm{eAD}, \mathbf{i}, 1 \mathrm{AD}$, $\mathbf{m}$ or $\mathrm{AD} / \mathrm{PD}$, n (magnification bar $100 \mu$ ). Anti- $\alpha$-synuclein antibody reveals Lewy bodies in the temporal cortex of $\mathrm{AD}$ (positive control), o, but no Lewy changes in the $\mathrm{ChP}$ from $\mathrm{H}$, $\mathbf{p}$, eAD, r, 1AD, s or AD/PD, t (magnification bar $100 \mu$ ). 
medRxiv preprint doi: https://doi.org/10.1101/2021.07.29.21260696; this version posted August 1, 2021. The copyright holder for this preprint (which was not certified by peer review) is the author/funder, who has granted medRxiv a license to display the preprint in All rights reserved. No reuse allowed without permission.

Extended Data Figure 3 - Unique and shared CSF proteins between AD and other disorders Venn diagram showing CSF proteins identified by both independent mass spectrometry approaches in mild cognitive impairment (MCI, $\mathrm{n}=10)$ and dementia (AD, $\mathrm{n}=22$ ) due to $\mathrm{AD}$, amyotrophic lateral sclerosis (ALS, $\mathrm{n}=14$ ) and Lyme disease (Lyme, $\mathrm{n}=12$ ) or in any of the resulting combinations.

Extended Data Figure 4 - CSF proteins changed in mild cognitive impairment, amyotrophic lateral sclerosis and Lyme's disease compared with AD Volcano plots showing individual protein changes in the CSF of patients with MCI $(n=10)$, ALS patients $(n=$ 14) and Lyme disease $(n=12)$ compared with $\operatorname{AD}(n=22)$ using two independent mass spectrometry approaches ( $\mathrm{A}$ and $\mathrm{B}, \mathrm{p} \leq 0.05)$.

Extended Data Figure 5 - Interactions between CSF proteins changed in mild cognitive impairment, amyotrophic lateral sclerosis and Lyme's disease compared with AD patients String plots depicting interactions between significantly increased and decreased CSF proteins in MCI $(n=10)$, ALS $(n=14)$ and Lyme $(n=12)$ compared with AD $(n=22)$ using two independent mass spectrometry approaches (A and B).

Extended Data Figure 6 - Validation of the identity of the proteotypic peptides used in the ChP targeted protein mass spectrometry Skyline iRT retention time prediction algorithm shows identical chromatogram retention times between proteotypic peptides used to quantify ChP proteins (bottom) and stable isotopically labelled synthetic peptides (top). Peptides in a were used for relative quantification.

Extended Data Figure 7 - No change in the cholesterol in the ChP between $H$ and AD Total and free cholesterol levels (ng/mg of dry ChP weight) in the ChP from $\mathrm{H}(\mathrm{n}=5)$ and AD $(\mathrm{n}=5)$ ChP. 1 technical replicate \pm s.e.m.; two-sample $t$-test $(\mathrm{p} \leq 0.05)$.

Extended Data Figure 8 - Validation of the identity of the gangliosides used in the ChP targeted ganglioside mass spectrometry Identical retention times between proteotypic GM1 and GM3 and isotopically labeled GM1 and GM3. Gangliosides were quantified using selected reaction monitoring (SRM) assays internally standardized with $1.5 \mu \mathrm{M}$ and $0.15 \mu \mathrm{M}$ of isotopically labeled GM1 and GM3, respectively. 
medRxiv preprint doi: https://doi.org/10.1101/2021.07.29.21260696; this version posted August 1, 2021. The copyright holder for this preprint (which was not certified by peer review) is the author/funder, who has granted medRxiv a license to display the preprint in All rights reserved. No reuse allowed without permission.

Extended Data Figure 9 - No lipid changes in the ChP between $\mathrm{H}$ and AD No difference in the levels of phosphatidylcholines PC34:0, PC34:1, PC34:2, PC36:1 and PC36:2, a, phosphatidylethanolamines PE-34:1, PE-36:2, PE-38:4 and PE-38:6, b, sphingomyelins $\operatorname{SM}(34: 1), \operatorname{SM}(36: 2)$ and $\operatorname{SM}(36: 1)$, c, phosphatidylinositols PI34:2, PI36:1, PI36:2, PI36:4, PI38:3, PI38:4 and PI38:5, d, phosphatidylserines PS34:1, PS36:1, PS36:2 and PS38:4, e, and sulfatides S36:1, S40:1, S41:1(OH), S41:2, S42:1, S42:1(OH), S42:2, S42:2(OH), S42:3, $\mathrm{S} 43: 2, \mathrm{~S} 43: 2(\mathrm{OH}), \mathrm{S} 43: 1(\mathrm{OH})$ and $\mathrm{S} 44: 2(\mathrm{OH}), \mathbf{f}$, in $\mathrm{ChP}$ between $\mathrm{H}(\mathrm{n}=5)$ and $\mathrm{AD}(\mathrm{n}=5) .6$ technical replicates \pm s.e.m.; two-sample $t$-test $(\mathrm{p} \leq 0.05)$.

Extended Data Figure 10 - Increased ChP volumes in AD compared with $H$ in a confirmatory cohort Normalized volumes of cerebellar cortices (negative control), hippocampi (positive control) and $\mathrm{ChP}$ in $\mathrm{H}(\mathrm{n}=13)$ and $\mathrm{AD}(\mathrm{n}=10) .1$ technical replicate \pm s.e.m.; two-sample $t$-test $(\mathrm{p} \leq 0.05)$.

\section{Supplementary information}

Reporting summary

Supplementary Tables 1-11.

\section{Source data}

Source Data Fig. 1

Source Data Fig. 2

Source Data Fig. 3

Source Data Fig. 4

Source Data Extended Data Fig.1

Source Data Extended Data Fig. 2

Source Data Extended Data Fig. 3

Source Data Extended Data Fig. 4

Source Data Extended Data Fig. 5

Source Data Extended Data Fig. 6

Source Data Extended Data Fig. 7

Source Data Extended Data Fig. 8

Source Data Extended Data Fig. 9

Source Data Extended Data Fig. 9 
medRxiv preprint doi: https://doi.org/10.1101/2021.07.29.21260696; this version posted August 1, 2021. The copyright holder for this preprint (which was not certified by peer review) is the author/funder, who has granted medRxiv a license to display the preprint in perpetuity.

All rights reserved. No reuse allowed without permission.

\section{Rights and permissions}

Rights and permissions 
medRxiv preprint doi: https://doi.org/10.1101/2021.07.29.21260696; this version posted August 1, 2021. The copyright holder for this preprint (which was not certified by peer review) is the author/funder, who has granted medRxiv a license to display the preprint in perpetuity.

All rights reserved. No reuse allowed without permission.

\section{References}

1 Hur, J. Y. et al. The innate immunity protein IFITM3 modulates gamma-secretase in Alzheimer's disease. Nature 586, 735-740, doi:10.1038/s41586-020-2681-2 (2020).

2 Heneka, M. T., McManus, R. M. \& Latz, E. Inflammasome signalling in brain function and neurodegenerative disease. Nat Rev Neurosci 19, 610-621, doi:10.1038/s41583-018-0055-7 (2018).

3 Sweeney, M. D., Sagare, A. P. \& Zlokovic, B. V. Blood-brain barrier breakdown in Alzheimer disease and other neurodegenerative disorders. Nat Rev Neurol 14, 133-150, doi:10.1038/nrneurol.2017.188 (2018).

4 Taipa, R. et al. Proinflammatory and anti-inflammatory cytokines in the CSF of patients with Alzheimer's disease and their correlation with cognitive decline. Neurobiol Aging 76, 125132, doi:10.1016/j.neurobiolaging.2018.12.019 (2019).

5 Gate, D. et al. Clonally expanded CD8 T cells patrol the cerebrospinal fluid in Alzheimer's disease. Nature 577, 399-404, doi:10.1038/s41586-019-1895-7 (2020).

6 Ciccocioppo, F. et al. Neurodegenerative diseases as proteinopathies-driven immune disorders. Neural Regen Res 15, 850-856, doi:10.4103/1673-5374.268971 (2020).

7 Shipley, F. B. et al. Tracking Calcium Dynamics and Immune Surveillance at the Choroid Plexus Blood-Cerebrospinal Fluid Interface. Neuron, doi:10.1016/j.neuron.2020.08.024 (2020).

8 Strominger, I. et al. The Choroid Plexus Functions as a Niche for T-Cell Stimulation Within the Central Nervous System. Front Immunol 9, 1066, doi:10.3389/fimmu.2018.01066 (2018).

9 Salvesen, O. et al. LPS-induced systemic inflammation reveals an immunomodulatory role for the prion protein at the blood-brain interface. I Neuroinflammation 14, 106, doi:10.1186/s12974-017-0879-5 (2017).

10 Cui, J. et al. Inflammation of the Embryonic Choroid Plexus Barrier following Maternal Immune Activation. Dev Cell 55, 617-628 e616, doi:10.1016/j.devcel.2020.09.020 (2020).

11 Yang, A. C. et al. Dysregulation of brain and choroid plexus cell types in severe COVID-19. Nature, doi:10.1038/s41586-021-03710-0 (2021).

12 Dani, N. et al. A cellular and spatial map of the choroid plexus across brain ventricles and ages. Cell 184, 3056-3074 e3021, doi:10.1016/j.cell.2021.04.003 (2021).

13 Zhu, L. et al. Klotho controls the brain-immune system interface in the choroid plexus. Proc Natl Acad Sci U S A 115, E11388-E11396, doi:10.1073/pnas.1808609115 (2018).

14 Baruch, K. et al. Aging. Aging-induced type I interferon response at the choroid plexus negatively affects brain function. Science 346, 89-93, doi:10.1126/science.1252945 (2014).

15 Balusu, S., Brkic, M., Libert, C. \& Vandenbroucke, R. E. The choroid plexus-cerebrospinal fluid interface in Alzheimer's disease: more than just a barrier. Neural Regen Res 11, 534-537, doi:10.4103/1673-5374.180372 (2016).

16 Baruch, K. et al. Breaking immune tolerance by targeting Foxp3(+) regulatory T cells mitigates Alzheimer's disease pathology. Nat Commun 6, 7967, doi:10.1038/ncomms8967 (2015).

17 Steeland, S. et al. Counteracting the effects of TNF receptor-1 has therapeutic potential in Alzheimer's disease. EMBO Mol Med 10, doi:10.15252/emmm.201708300 (2018).

18 Brkic, M. et al. Amyloid beta Oligomers Disrupt Blood-CSF Barrier Integrity by Activating Matrix Metalloproteinases. J Neurosci 35, 12766-12778, doi:10.1523/JNEUROSCI.000615.2015 (2015).

19 Gonzalez-Marrero, l. et al. Choroid plexus dysfunction impairs beta-amyloid clearance in a triple transgenic mouse model of Alzheimer's disease. Front Cell Neurosci 9, 17, doi:10.3389/fncel.2015.00017 (2015).

$20 \mathrm{Xu}, \mathrm{Z}$. et al. A combination of lycopene and human amniotic epithelial cells can ameliorate cognitive deficits and suppress neuroinflammatory signaling by choroid plexus in Alzheimer's disease rat. J Nutr Biochem 88, 108558, doi:10.1016/j.jnutbio.2020.108558 (2020). 
medRxiv preprint doi: https://doi.org/10.1101/2021.07.29.21260696; this version posted August 1, 2021. The copyright holder for this preprint (which was not certified by peer review) is the author/funder, who has granted medRxiv a license to display the preprint in perpetuity.

All rights reserved. No reuse allowed without permission.

21 Tadayon, E., Pascual-Leone, A., Press, D., Santarnecchi, E. \& Alzheimer's Disease Neuroimaging, I. Choroid plexus volume is associated with levels of CSF proteins: relevance for Alzheimer's and Parkinson's disease. Neurobiol Aging 89, 108-117, doi:10.1016/j.neurobiolaging.2020.01.005 (2020).

22 Serot, J. M., Bene, M. C., Foliguet, B. \& Faure, G. C. Morphological alterations of the choroid plexus in late-onset Alzheimer's disease. Acta Neuropathol 99, 105-108, doi:10.1007/pl00007412 (2000).

23 Kant, S., Stopa, E. G., Johanson, C. E., Baird, A. \& Silverberg, G. D. Choroid plexus genes for CSF production and brain homeostasis are altered in Alzheimer's disease. Fluids Barriers CNS 15, 34, doi:10.1186/s12987-018-0120-7 (2018).

24 Silverberg, G. D. et al. The cerebrospinal fluid production rate is reduced in dementia of the Alzheimer's type. Neurology 57, 1763-1766, doi:10.1212/wnl.57.10.1763 (2001).

25 Corder, E. H. et al. Gene dose of apolipoprotein E type 4 allele and the risk of Alzheimer's disease in late onset families. Science 261, 921-923, doi:10.1126/science.8346443 (1993).

26 Yin, C. et al. ApoE attenuates unresolvable inflammation by complex formation with activated C1q. Nat Med 25, 496-506, doi:10.1038/s41591-018-0336-8 (2019).

27 Raha-Chowdhury, R. et al. Choroid Plexus Acts as Gatekeeper for TREM2, Abnormal Accumulation of ApoE, and Fibrillary Tau in Alzheimer's Disease and in Down Syndrome Dementia. J Alzheimers Dis 69, 91-109, doi:10.3233/JAD-181179 (2019).

28 Serot, J. M., Bene, M. C. \& Faure, G. C. Choroid plexus, aging of the brain, and Alzheimer's disease. Front Biosci 8, s515-521, doi:10.2741/1085 (2003).

29 Onyango, I. G., Jauregui, G. V., Carna, M., Bennett, J. P., Jr. \& Stokin, G. B. Neuroinflammation in Alzheimer's Disease. Biomedicines 9, doi:10.3390/biomedicines9050524 (2021).

30 Higginbotham, L. et al. Integrated proteomics reveals brain-based cerebrospinal fluid biomarkers in asymptomatic and symptomatic Alzheimer's disease. Sci Adv 6, doi:10.1126/sciadv.aaz9360 (2020).

31 Johnson, E. C. B. et al. Large-scale proteomic analysis of Alzheimer's disease brain and cerebrospinal fluid reveals early changes in energy metabolism associated with microglia and astrocyte activation. Nat Med 26, 769-780, doi:10.1038/s41591-020-0815-6 (2020).

32 Scheltens, P. et al. Alzheimer's disease. Lancet 397, 1577-1590, doi:10.1016/S01406736(20)32205-4 (2021).

33 Pellegrini, L. et al. Human CNS barrier-forming organoids with cerebrospinal fluid production. Science 369, doi:10.1126/science.aaz5626 (2020).

34 Pearson, A. et al. Molecular abnormalities in autopsied brain tissue from the inferior horn of the lateral ventricles of nonagenarians and Alzheimer disease patients. BMC Neurol 20, 317, doi:10.1186/s12883-020-01849-3 (2020).

35 Zhou, S. et al. Endosomal/lysosomal processing of gangliosides affects neuronal cholesterol sequestration in Niemann-Pick disease type C. Am J Pathol 179, 890-902, doi:10.1016/j.ajpath.2011.04.017 (2011).

36 Seab, J. P. et al. Quantitative NMR measurements of hippocampal atrophy in Alzheimer's disease. Magn Reson Med 8, 200-208, doi:10.1002/mrm.1910080210 (1988).

37 Gruver, A. L., Hudson, L. L. \& Sempowski, G. D. Immunosenescence of ageing. J Pathol 211, 144-156, doi:10.1002/path.2104 (2007).

38 Lee, C. K., Weindruch, R. \& Prolla, T. A. Gene-expression profile of the ageing brain in mice. Nat Genet 25, 294-297, doi:10.1038/77046 (2000).

39 Lu, T. et al. Gene regulation and DNA damage in the ageing human brain. Nature 429, 883891, doi:10.1038/nature02661 (2004).

40 Sweeney, M. D., Kisler, K., Montagne, A., Toga, A. W. \& Zlokovic, B. V. The role of brain vasculature in neurodegenerative disorders. Nat Neurosci 21, 1318-1331, doi:10.1038/s41593-018-0234-x (2018).

41 Sweeney, M. D. \& Zlokovic, B. V. A lymphatic waste-disposal system implicated in Alzheimer's disease. Nature 560, 172-174, doi:10.1038/d41586-018-05763-0 (2018). 
medRxiv preprint doi: https://doi.org/10.1101/2021.07.29.21260696; this version posted August 1 , 2021. The copyright holder for this preprint (which was not certified by peer review) is the author/funder, who has granted medRxiv a license to display the preprint in perpetuity.

All rights reserved. No reuse allowed without permission.

42 Benson, M. D. et al. Suppression of choroid plexus transthyretin levels by antisense oligonucleotide treatment. Amyloid 17, 43-49, doi:10.3109/13506129.2010.483121 (2010).

43 Sheardova, K. et al. Czech Brain Aging Study (CBAS): prospective multicentre cohort study on risk and protective factors for dementia in the Czech Republic. BMJ Open 9, e030379, doi:10.1136/bmjopen-2019-030379 (2019).

44 Russo, M. J. et al. Creation of the Argentina-Alzheimer's Disease Neuroimaging Initiative. Alzheimers Dement 10, S84-87, doi:10.1016/j.jalz.2013.09.015 (2014).

45 Saul, J. et al. Global alterations to the choroid plexus blood-CSF barrier in amyotrophic lateral sclerosis. Acta Neuropathol Commun 8, 92, doi:10.1186/s40478-020-00968-9 (2020).

46 Ruffmann, C. et al. Cortical Lewy bodies and Abeta burden are associated with prevalence and timing of dementia in Lewy body diseases. Neuropathol Appl Neurobiol 42, 436-450, doi:10.1111/nan.12294 (2016).

47 Vanderstichele, H. et al. Standardization of preanalytical aspects of cerebrospinal fluid biomarker testing for Alzheimer's disease diagnosis: a consensus paper from the Alzheimer's Biomarkers Standardization Initiative. Alzheimers Dement 8, 65-73, doi:10.1016/j.jalz.2011.07.004 (2012).

48 Prokopenko, I. et al. Alzheimer's disease pathology explains association between dementia with Lewy bodies and APOE-epsilon4/TOMM40 long poly-T repeat allele variants. Alzheimers Dement (N Y) 5, 814-824, doi:10.1016/j.trci.2019.08.005 (2019).

49 Shinohara, R. T. et al. Statistical normalization techniques for magnetic resonance imaging. Neuroimage Clin 6, 9-19, doi:10.1016/j.nicl.2014.08.008 (2014).

50 Desikan, R. S. et al. An automated labeling system for subdividing the human cerebral cortex on MRI scans into gyral based regions of interest. Neuroimage 31, 968-980, doi:10.1016/j.neuroimage.2006.01.021 (2006).

51 Fischl, B. et al. Whole brain segmentation: automated labeling of neuroanatomical structures in the human brain. Neuron 33, 341-355, doi:10.1016/s0896-6273(02)00569-x (2002).

52 Reuter, M., Schmansky, N. J., Rosas, H. D. \& Fischl, B. Within-subject template estimation for unbiased longitudinal image analysis. Neuroimage 61, 1402-1418, doi:10.1016/j.neuroimage.2012.02.084 (2012).

53 Avants, B. B., Epstein, C. L., Grossman, M. \& Gee, J. C. Symmetric diffeomorphic image registration with cross-correlation: evaluating automated labeling of elderly and neurodegenerative brain. Med Image Anal 12, 26-41, doi:10.1016/j.media.2007.06.004 (2008). 


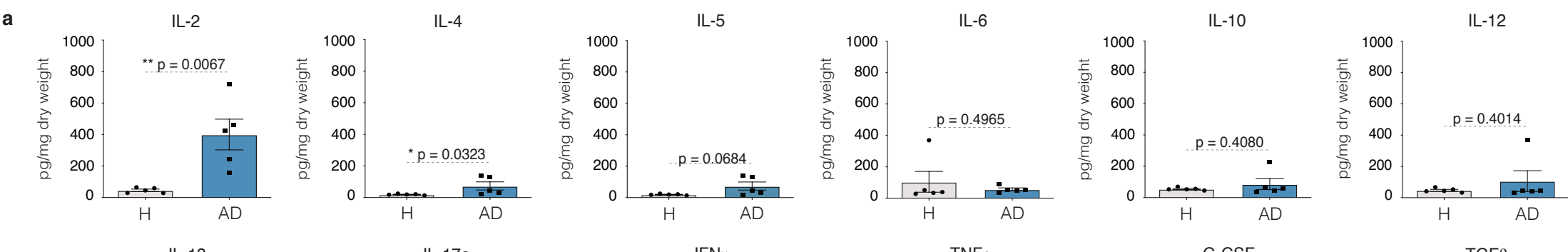

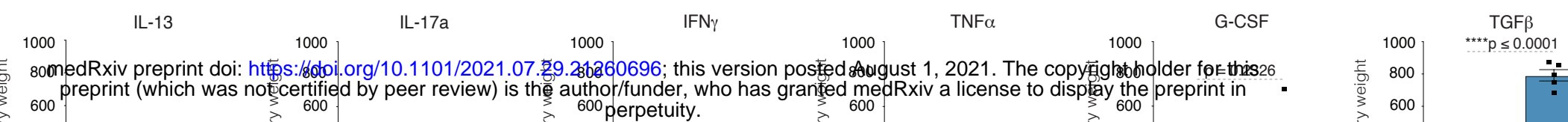

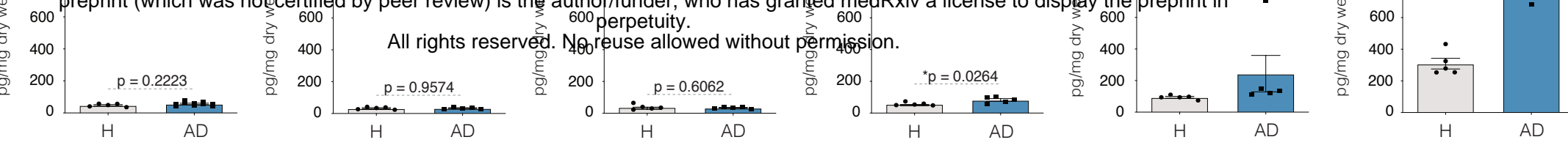

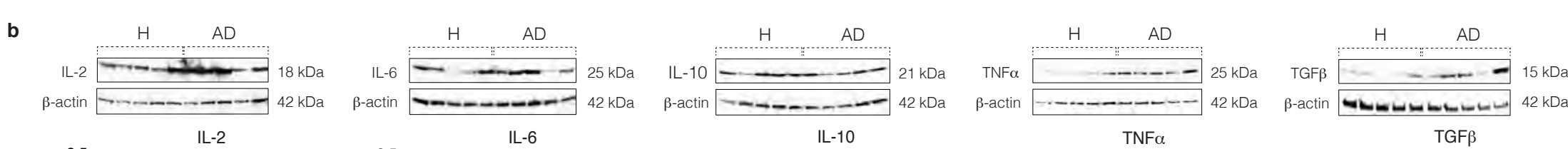

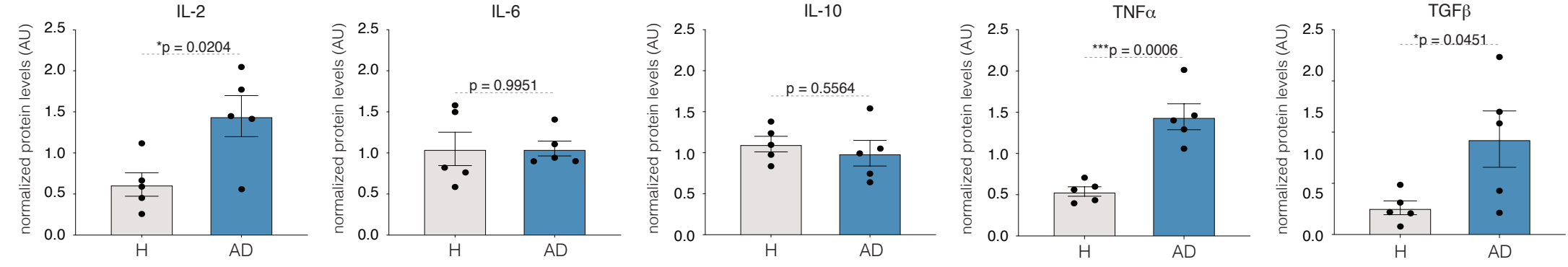




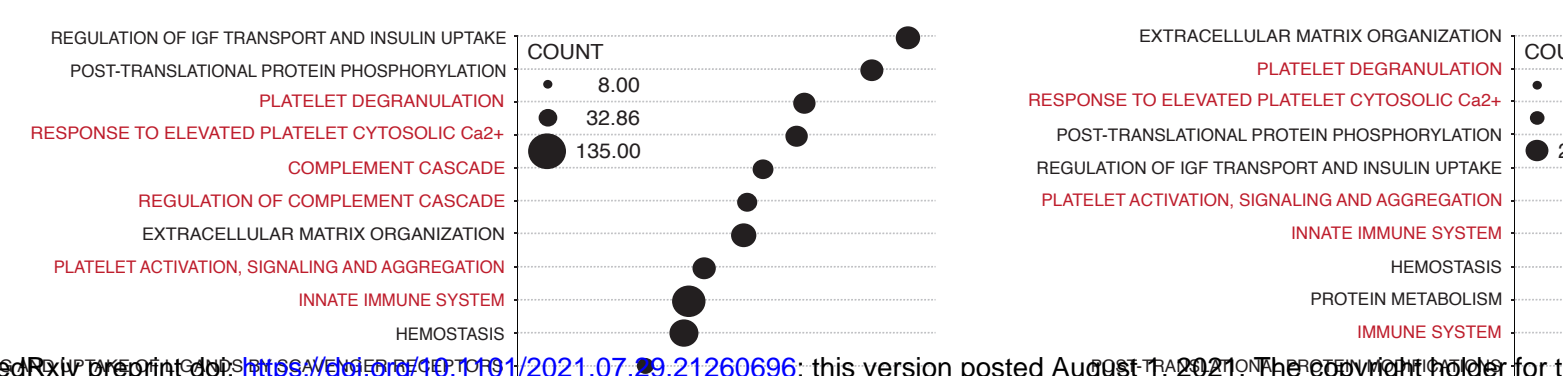

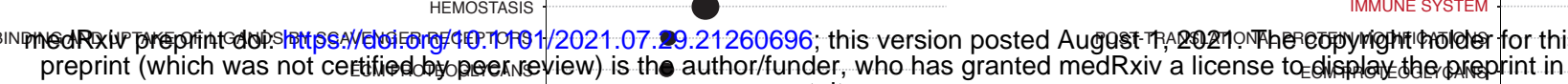

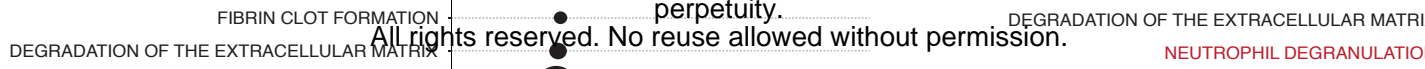
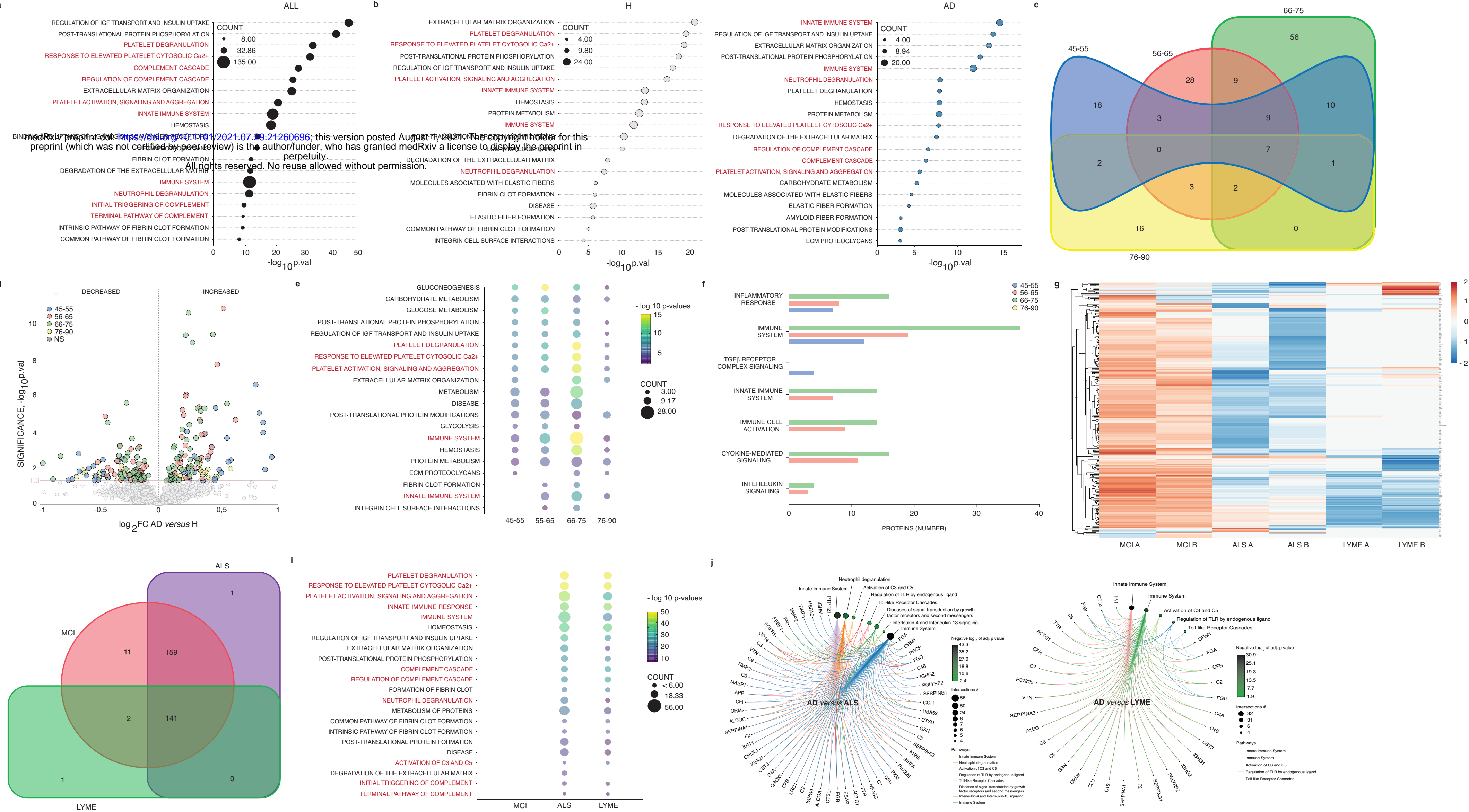


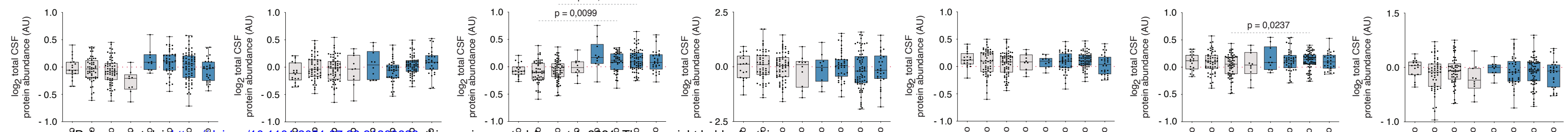

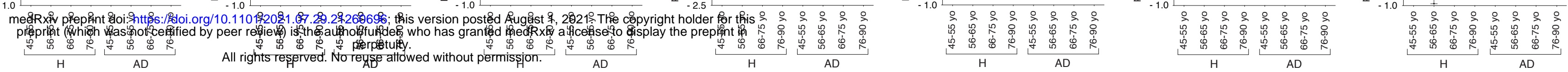
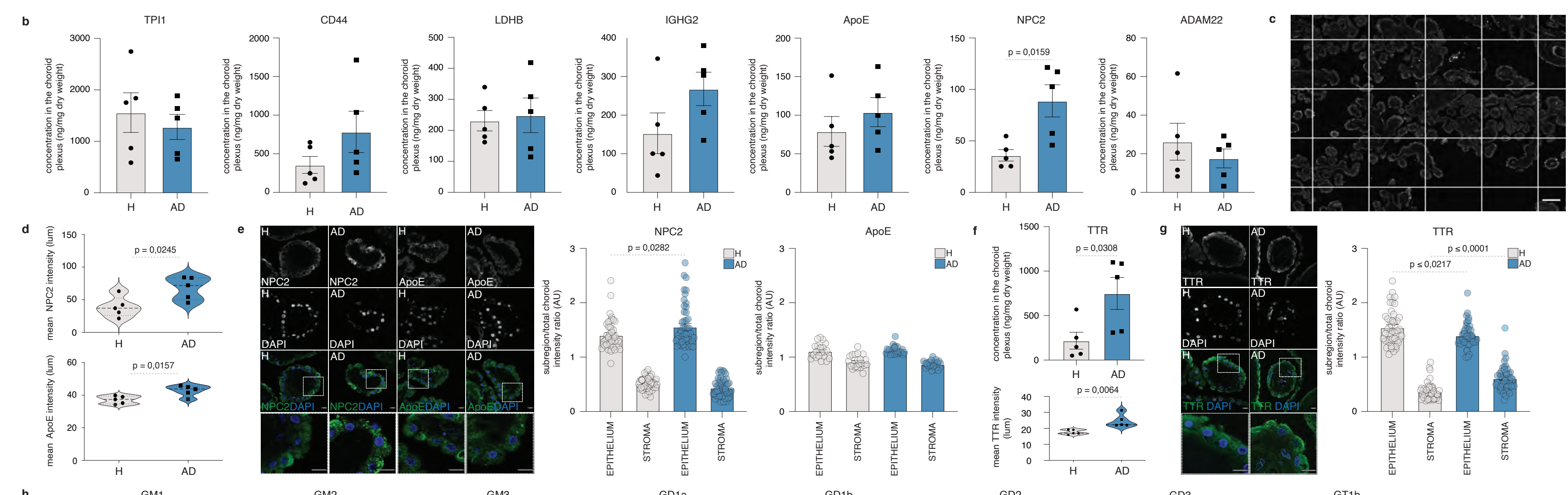

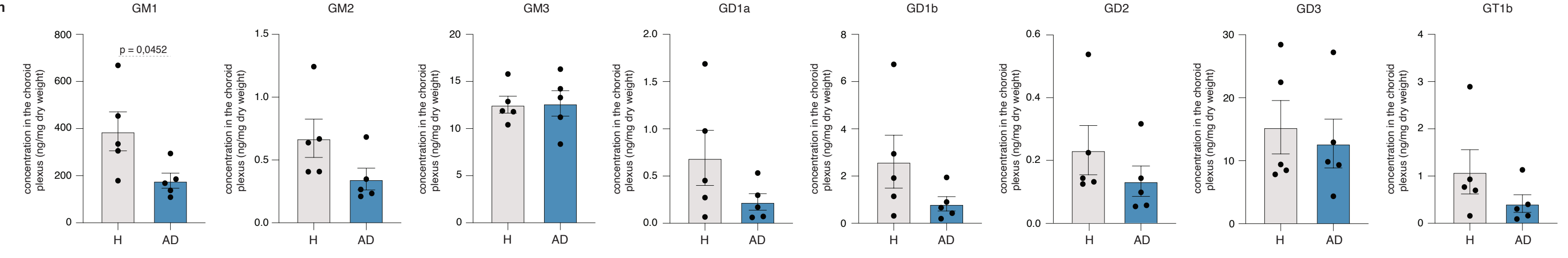




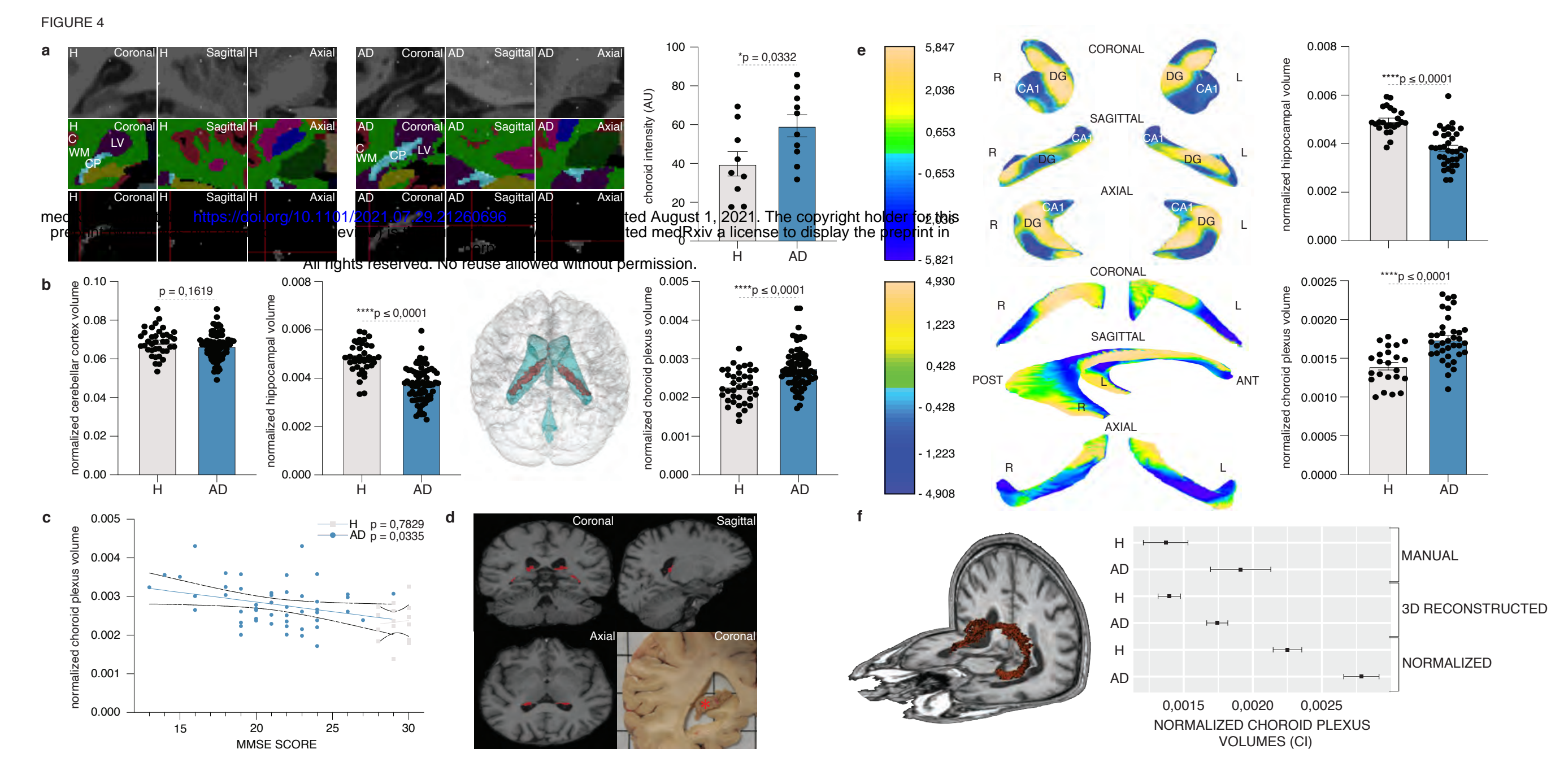

